Article

\title{
Strategic Decisions between Short-Term Profit and Sustainability
}

\section{Philipp Haessler(D)}

Department of Knowledge and Technology Transfer, University of Stuttgart, 70174 Stuttgart, Germany; philipp.haessler@ets.uni-stuttgart.de

Received: 2 August 2020; Accepted: 20 August 2020; Published: 1 September 2020

\begin{abstract}
Sustainability has evolved into one of the key topics for organizations and organizational researchers alike. To meet changing societal demands, organizations have to adapt their long-term strategies and incorporate environmental and social aspects into their product offerings and decision-making. However, at the same time companies must satisfy short-term profitability interests and demands from shareholders. An organization's sustainability commitment, strategy, or view is impacted by several influential factors, e.g., by the top management commitment or stakeholder integration. These factors have largely been studied individually without linking them. As such, the following study aims at creating a holistic view and framework for organizational influences and on sustainability. The framework is validated by a comparison to industrial practice in interviews with sustainability managers from the chemical and automobile industry, which are both highly relevant in the context of sustainability. Interview results suggest that the identified influential factors attributed to the four framework layers organization, top management, project team and project are relevant for industrial representatives. The view on and impact of specific influential factors can vary between companies and industries. The study further gives insights into the actual status and future direction of the management of corporate sustainability (CS) in practice.
\end{abstract}

Keywords: corporate sustainability; influential factors; corporate sustainability performance; trade-offs; chemical industry; automotive industry; decision-making

\section{Introduction}

In recent times, continuing and accelerating environmental degradation has become a concern in society, politics, and business alike (Revell et al. 2010). The rising consumer concern for environmental issues, especially in the younger generation, e.g., "Fridays for Future" (von Wehrden et al. 2019) and stricter government regulations are creating a major challenge for businesses to become more responsible with their business operations (Cabot et al. 2009).

Companies are increasingly integrating concepts such as the triple-bottom-line (TBL) (Elkington 1997), corporate social responsibility (CSR) (Chernev and Blair 2015; Devinney 2009) and sustainability (Kuhlman and Farrington 2010) into their business and leading companies have recognized the need to proactively manage their social and environmental impacts to achieve business success (Epstein and Wisner 2001). The corresponding term corporate sustainability (CS) can be seen as integrating sustainability considerations from a profit perspective (Dyllick and Hockerts 2002; Baumgartner 2009).

Nonetheless, profitability is viewed as the primary output and concern for business (Kolstad 2007). While the financial benefits of some sustainability topics are clear, e.g., reduction of costs by limiting energy demand, financial benefits of investments in green technology and processes are not as clear and underlie uncertainty (Ball 2011).

As a result, managers are tasked with balancing trade-offs between profitability and sustainable value creation. Epstein et al. (2015) found that managers choose profitability over sustainability 
whenever they are in conflict (Epstein et al. 2015). Moreover, a study analyzing 400 companies found that managers readily forego long-term value creation in order to meet short-term targets (Graham et al. 2005). As such, short-term thinking in companies still has a big influence (Bansal and DesJardine 2014) and is in apparent conflict with sustainability of which benefits accrue over the long-term (Aragon-Correa et al. 2017).

The question arises as to which factors influence sustainability in organizations and make them decide in favor of short-term profit or sustainability, respectively. As such, the following study sheds light on key factors that influence sustainability in an organization. As a tool for analysis, a conceptual framework mapping the factors to areas within an organization was developed and later validated and expanded using qualitative data analysis.

\subsection{Aim and Approach}

Current sustainability literature predominantly research areas that deal with explaining the benefits of sustainability and their measurement, the strategic role in organizations and managerial practices as well as other factors that influence decisions and sustainable performance. Research has identified several factors that might impact sustainable decision-making and analyzed them individually. Therefore, the following study aims to decrease the research gap and draw existing literature together to form a holistic view on influential factors.

For this purpose, the central research question that is answered is how managers and companies are perceiving key influential factors on sustainability. Whenever possible, first impulses and results toward management of these factors and their inter-relationships are provided.

The first step is to lay the conceptual groundwork regarding sustainability. During this step, a basic understanding of sustainability and the underlying challenge of short-term profit and sustainability consolidation is established. Furthermore, influential factors are outlined and briefly described. Moreover, the analysis framework will be set up concluding the theoretical background.

Hereafter, with the help of semi-structured expert interviews in selected companies from the chemical and automotive industry, influential factors on sustainability will be analyzed in a qualitative study. The chemical and automobile industry were chosen due to their relevance in the context of sustainability. Due to the increased importance of environmental developments (Revell et al. 2010) the underlying study will mainly focus on environmental sustainability in organizations. However, sustainability also encompasses the social dimension and as such, it will not be left out here.

Interview analysis is based on an approach consisting of descriptive coding as well as pattern coding. Subsequently, findings are compared to each other as well as cross-industry, where applicable. Afterwards, the findings are discussed and analyzed within the context of the existing literature. The identified influential factors are highlighted using the developed framework.

Finally, the study concludes by highlighting main influencing factors for sustainability and related decision-making in organizations. Furthermore, limitations of the study and recommendations for future research are given.

\subsection{Research Significance}

The term "sustainability" has become the business term of the 21st century. To prosper in the 21st century, businesses must enhance and at the same time balance their economic, social, and environmental performance. The same holds true for academic research. Numerous studies on the topic of sustainability and CSR have been conducted (Galpin et al. 2015). While most of them have dealt with analyzing the link between sustainability and financial performance (Epstein and Roy 2003) as well as benefits and motivations of sustainability (Berns et al. 2009), recent research has aimed at analyzing how companies can integrate sustainability into their decision-making (Alexander et al. 2014).

Some studies highlight the role of "Stakeholder Theory" in decision-making and the importance of stakeholders in the management of sustainability (Hörisch et al. 2014), while others postulate new models to evaluate the benefits of sustainability and create a business case for sustainability (Cabot et 
al. 2009). Furthermore, it is suggested that top-managerial commitment plays a vital role for greater sustainable performance (Walker et al. 2015). However, while the studies are certainly correct in researching these areas as they are evidently relevant for sustainability, research must look at influential factors in an integrative way since they have a combined effect on sustainability rather than considering them in isolation.

Consequently, there is a need to develop a conceptual framework that summarizes and gives a holistic view on influential factors for sustainability in organizations. The existing literature has hardly explored such a holistic view. Thus, this research is a novel contribution to academic research and managerial practice and supports the understanding of sustainability from a company's perspective. However, it should be noted that the sample size is limited and thus only a limited generalizability is possible.

\section{Materials and Methods}

The following initial section lays the conceptual groundwork for the subsequent study. First, the understanding of sustainability and the challenges regarding sustainability in organizations will be outlined. Following, influential factors on sustainability will be described. In a final step, the conceptual framework for the subsequent analysis will be established.

Sustainability is extremely widely covered in the literature. Therefore, Figure 1 shows the methodology used to identify key literature and consequently also key influential factors (see the Supplementary Materials for the full procedure).

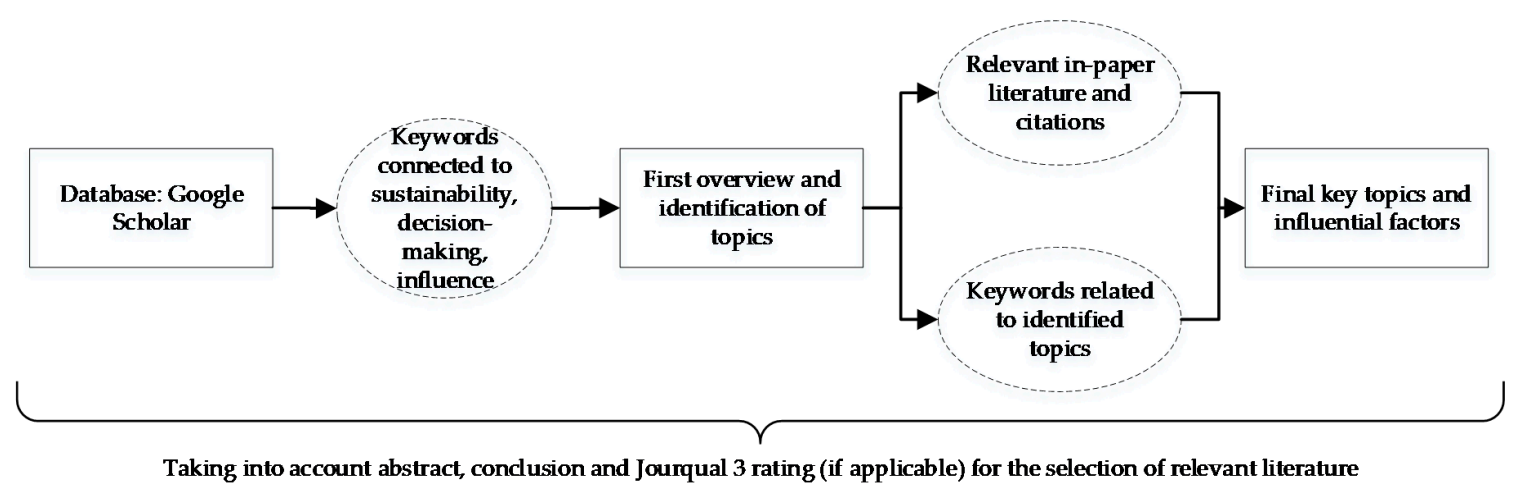

Figure 1. Methodology of the literature search and identification of influential factors.

\subsection{Corporate Sustainability and Related Challenges}

Sustainability has become the buzzword of the 21st century (Galpin et al. 2015). All over the world, organizations are being driven to become more responsible by stricter government regulations (Cabot et al. 2009), the emergence of customers and end consumers emphasizing the importance of green, sustainable, and fair products (IBM 2008) and the naturally growing market for sustainable products (Alberti and Garrido 2017). Companies are therefore increasingly integrating sustainability as a business driver.

However, what is essentially meant by sustainability or concepts such as CSR or the TBL? All of these concepts have in common that they mean improving the three core dimensions of economic, social, and environmental nature (Galpin et al. 2015). The integration of social and environmental aspects, in addition to the traditional financial bottom-line, was coined already early as the TBL by Elkington (1997).

However, it can be argued that the concept of sustainability is more complex than three different bottom-lines would imply. Today, the most common definition goes back to the "Brundtland Report" of the United Nations, defining sustainability as "the development that meets the needs of the present without compromising the ability of future generations to meet their own needs" (Brundtland 1987). Since then this definition has been widely adopted and built upon by researchers, e.g., introducing 
the concept of time into sustainability where sustainability is defined in a similar manner regarding short-term and long-term financial needs (Bansal and DesJardine 2014).

Sustainability has emerged as an important topic for businesses. However, short-term financial value is still a primary goal of organizations. Businesses are challenged to find both economic sustainability as well as environmental and social sustainability within their organizations (Schaltegger et al. 2012). The concept of CS integrates the view that sustainability has to establish a clear business case for organizations (Dyllick and Hockerts 2002; Baumgartner 2009).

Consequently, CS can be seen as new profit-motivated response to current challenges of business operations' environmental and social issues (Salzmann et al. 2005).

As demonstrated, sustainability is still surrounded by a high degree of ambiguity with no clear definition in sight. Furthermore, CS integration is attached to multiple challenges for companies.

One of the most prominent topics in sustainability-related research is the existence of trade-offs in the practical application of sustainability. Hahn et al. (2010) for example state that "trade-offs are indeed the rule rather than the exception" (Hahn et al. 2010). Thus, achieving maximum performance in all three dimensions-social, environmental, and financial-is very difficult.

There have been several research papers documenting the variety of trade-offs found in an organization. On a higher level, companies have to decide between engaging in sustainable value along the three dimensions (Haffar and Searcy 2017) or private value (Porter and Kramer 2011). More specifically, there also exist trade-offs in the choice of which areas to engage in (Csutora 2011) and how to engage in them (Haffar and Searcy 2017). While the overarching trade-off plays a more fundamental role, trade-offs are convoluted and influence each other (Haffar and Searcy 2017). It is not only about reconciling profitability and sustainability anymore but rather which sustainability aspect to target (Winn et al. 2012) and how to achieve it (Hahn et al. 2012).

Nonetheless, the primary trade-offs still lie in profitability versus sustainability conflicts where researchers found that managers tend to decide in favor of financial performance whenever sustainability and financial performance are at odds (Epstein et al. 2015). Moreover, this trade-off seems to be more pronounced over time (Laverty 1996) and especially in connection to sustainability areas that are linked to long-time horizons (Berns et al. 2009).

Currently, three approaches exist explaining how the conflict between both targets can be seen. In a first model, integrating sustainability inevitably requires trade-offs and has to be dealt with (Alberti and Garrido 2017; Varenova et al. 2013). Other authors state that those trade-offs can be overcome under suitable conditions (Hahn et al. 2010; Beckmann et al. 2014) and lastly, changing the business model in a way it conforms with sustainability goals primarily (Alberti and Garrido 2017).

Consequently, the three dimensions social, environmental, and financial are not perfectly aligned but also not opposed. In general, it is not possible for companies to find profitable sustainability opportunities without looking for them actively (Hart and Dowell 2011) and organizations can deal with this challenge in several ways (Morris and Su 1999).

A good sustainability performance seems to a great degree to be a result of good organizational decision-making (Haffar and Searcy 2017) in the presence of trade-offs (Retief et al. 2013). However, organizations are still figuring out how to best balance these trade-offs especially regarding short-term profitability and long-term sustainability in a dynamic business environment.

So far, literature has mostly reviewed single influential factors on CS. A holistic view on crucial factors influencing CS and related decision-making is needed but missing at this moment. As such, the following section outlines factors influencing CS that were addressed in prior literature and attempt to integrate them in a holistic organizational framework.

\subsection{Influential Factors on Sustainability in Organizations}

In the literature, several main and surprisingly diverse factors are mentioned that can impact the practice of the CS area. Table 1 at the end of this section gives an overview of the most important factors. 
Sustainability is integrated into organizations due to multiple drivers that have been intensively discussed in the literature. For an overview, see e.g. (Schaltegger et al. 2012; Lozano 2015; Oertwig et al. 2017; Giunipero et al. 2012; Epstein and Roy 2001).

Most studies focus on identifying key drivers and categorizing them. For example, grouping them into external and internal drivers (Engert et al. 2016), ranking drivers into high, middle, and low effect drivers (Giunipero et al. 2012) or introducing connecting drivers which would connect internal and external drivers (Oertwig et al. 2017).

Studies also found different results analyzing the most important drivers. One source states that internally top management engagement is most important, whereas complying with laws and regulations is crucial externally (Lozano 2015; Giunipero et al. 2012). Lozano (2015) states that external drivers elicit reactive responses from companies while internal drivers lead to a proactive behavior of the company (Lozano 2015). In this regard, company strategies can be categorized into defensive, accommodative, and proactive approaches (Schaltegger et al. 2012).

Another influential factor is the overall financial situation of the company. In some cases, sustainability is aligned with classic operational goals, e.g., cost reductions by reduction of energy usage. However, investments in green technology often initially require high costs in the short-term and possibly no cost-savings or benefits immediately (Wu and Pagell 2011). Two studies found a positive correlation between the profitability of a company and CS performance (CSP) (Margolis et al. 2011; Artiach et al. 2010) suggesting that higher profitability is beneficial for CS and CS in turn needs to be affordable. Similarly, it is assumed that phases of economic downturn can negatively affect organizations and sustainability (Placier 2011). In times of poor financial performance, pressure on increasing profitability is rising and social and environmental considerations are superseded by economic interests (Ullmann 1985).

Even though, laws and regulations in general play a role as a core driver the influence of politics and regulation on a local country level, e.g., US or Europe should be highlighted. The US has gone back from their leadership position on environmental regulation from the early 1990s. In contrast, the EU has risen as the leading lawmaker of international environmental law (Kelemen and Knievel 2015). Concerning regulations on climate change and packaging waste, US regulations are often less stringent. Scholars explain this by the lack of central regulations from the US government (Vogel et al. 2010) and by domestic politics focusing on economic considerations (Kelemen and Knievel 2015). Furthermore, European companies are also in a leading position with respect to reporting and accuracy of environmental data (Tînjală et al. 2015).

A key influential factor and driver of sustainability is the top management team (TMT). Depending on TMT attitude it can be both a hindering and a supporting factor for sustainability (Engert et al. 2016). TMT commitment also helps with establishing social and environmental reporting (Fifka 2013). Commitment and engagement by TMT are crucial factors needed for a high CSP (Walker et al. 2015; Tang et al. 2018).

Furthermore, a study analyzing the effects of TMT composition found a positive correlation between functional diversity within a TMT and CSP (Henry et al. 2019).

Moreover, having a long-term strategic view is essential for the TMT and as already stated above CS usually targets long-time horizons. However, short-termism is often still the practice (Bansal and DesJardine 2014) and most companies still prioritize short-term profitability. Nonetheless, in order to succeed both a long-term and a short-term perspective need to be present and complementary in a company (Hörisch et al. 2014).

Another influential factor can be seen in an organization following the logic of profit maximization. Managers might decide against sustainability whenever its targets are not aligned with traditional financial value (Epstein et al. 2015). For example, according to Alexander (2007) decisions in favor of CS increase costs at least in the short-term which would in turn decrease return on investment (ROI) or increase the total cost of product (TCP) which can in turn result in "avoidable harm" and thus managers would generally avoid such decisions (Alexander 2007). He concludes that companies 
should shift their primary filter value away from a full finance focus (Alexander 2007). As such, it would be interesting to investigate how companies deal with the issue of CS and short-term profit maximization possibly contradicting each other.

Moreover, influential factors are related to projects in organizations. Project assessment for sustainability is difficult since the strategies and impacts are usually connected to long-time horizons and benefits are additionally hard to quantify in a financial parameter (Epstein and Roy 2001). The need for tools to effectively connect social and environmental impacts to financial parameters arises (Epstein and Roy 2001). In this regard, studies have proposed and developed new algorithms, e.g., based on pareto-optimal combinations to better try to model sustainability and profitability tradeoffs (deVoil et al. 2006). However, even those approaches are flawed as the weighting still remains with the decision-maker (Haffar and Searcy 2017). Decisions can thus still mainly be based on financial parameters and standard processes, e.g., net present value (NPV), cost-benefit analysis (CBA) and hardly integrate qualitative benefits of sustainability in a methodical way (De Groot et al. 2010; Liesen et al. 2013). However, the combination of both is necessary in order to make effective decisions for CS (Epstein and Widener 2010). The way each company approaches project assessments will thus critically influence the sustainability area.

In addition, Gibson (2006) states that CS decisions must begin by integrating sustainability at the earliest opportunity where scope and purpose is established or else the project will focus on "damage reduction" rather than pro-activity in the sustainability area (Gibson 2006).

Lastly, as organizations have limited resources, sustainability initiatives might face competition for resources from other projects. Consequently, managers have to decide to increase profitable or sustainable value (Teng et al. 2014) or might be faced with incurred opportunity costs (Haffar and Searcy 2017). It will be noteworthy to analyze how managers view and address these challenges in today's practice.

A broader factor influencing sustainability is the application of "Stakeholder Theory" in organizations, which is common in both business and the social areas (Reynolds et al. 2006). In the literature, scholars argue that it is mainly due to stakeholder demands that firms adopt sustainability practices (Buysse and Verbeke 2003; Garcés-Ayerbe et al. 2012) and found that the society has become an increasingly demanding stakeholder (Bodhanwala and Bodhanwala 2018) and that organizations are now looking at stakeholders previously not considered, e.g., non-governmental organizations (NGOs) (Pagell and Wu 2009). Different types of stakeholder influences lead to different sustainability goals (Sharma and Henriques 2005).

Nonetheless, definition and perceived importance of stakeholders depend on individuals within organizations. A study found that managers see stakeholders along related business processes of the company and therefore often hold a rather narrow view of stakeholders (Pedersen 2011). The view on stakeholders can be different in different parts of the organization depending on which processes are in proximity of the organizational part or individual. Organizations will only integrate sustainability practices which do not decrease profitability and are aligned with their stakeholder mindset (Varenova et al. 2013). As such, the question arises how balanced the stakeholder portfolio of a company is and if there exist priorities, e.g., for stakeholders representing financial markets.

Lastly, sustainability-related decision-making and influences in this area needs to be looked at. Sustainability is a very important long-term direction for companies but a highly complex field which leads to a high degree of uncertainty (Wu and Pagell 2011). Decisions around CS are mostly always long-term in nature with a varying degree of uncertainty due to difficulties in quantifying the impact of financial benefits. However, in these cases decision-making is more difficult for individuals and teams (Retief et al. 2013). As such, it will certainly impact sustainability decisions and organizations need to be aware of this fact and manage it.

Related to that, decision-making theory suggests the concept of bounded rationality under uncertainty (Simon 2000). During decision-making, managers and teams are influenced by various biases or the use of heuristics, i.e., cognitive limitations that limit rationality (Tversky and Kahneman 
1974). A relevant bias is e.g., the status quo bias giving preference to already existing solutions (Samuelson and Zeckhauser 1974). Moreover, humans are impacted by their own personal goals, aspirations, and fear of loss (Certo et al. 2008). Scholars also found that managers are also acting under bounded rationality when it comes to managing sustainable supply chains (Walker et al. 2014). Sustainability decision-making is therefore and due to the high degree of uncertainty influenced by personal attitudes, experiences, and biases. Cognitive limitations certainly influence overall but are pronounced under uncertainty.

Studies so far have hardly addressed a holistic view on influences on CS in organizational practice beyond the concept of general drivers. Earlier scholars have studied influences largely individually, e.g., the influence of TMT commitment or the assessment of sustainability benefits. All previous studies argue that these different individual factors influence the adoption of CS in organizations but do not provide a link to other influencing factors. Consequently, the need for a holistic view on all relevant factors arises. The goal of the framework is to support the analysis and answer of the central research question which is as follows: How are managers and companies perceiving key influential factors on sustainability.

Overall, a multitude of factors from different research areas were identified. Table 1 gives an overview of the factors and their effects which have been outlined above.

Table 1. Summary of influential factors on CS in companies.

\begin{tabular}{|c|c|}
\hline Influential Factor & Influence \\
\hline \multicolumn{2}{|l|}{ External Factors } \\
\hline Sustainability Drivers & $\begin{array}{l}\text { Drivers for sustainability are the main reasons companies started looking at } \\
\text { sustainability, see e.g., (Schaltegger et al. 2012; Lozano 2015) }\end{array}$ \\
\hline $\begin{array}{l}\text { Financial Situation of the } \\
\text { Company }\end{array}$ & $\begin{array}{l}\text { Profitability and CSP are positively linked (Artiach et al. 2010) and CS needs to be } \\
\text { affordable }\end{array}$ \\
\hline Local politics on country level & $\begin{array}{l}\text { Differences between environmental regulation, e.g., US and Europe (Kelemen and } \\
\text { Knievel 2015) could be an influential factor }\end{array}$ \\
\hline \multicolumn{2}{|l|}{ Top Management } \\
\hline Engagement, commitment & $\begin{array}{l}\text { Engagement and commitment on sustainability by top management is crucial in the } \\
\text { context of sustainability (Tang et al. 2018) }\end{array}$ \\
\hline Functional diversity & $\begin{array}{l}\text { Presence of a functional diverse top management has a positive impact on sustainability } \\
\text { (Henry et al. 2019) }\end{array}$ \\
\hline Long-term perspective & Long-term perspective is essential for sustainability (Bansal and DesJardine 2014) \\
\hline Profit maximization & $\begin{array}{l}\text { Businesses are used to follow the route of profit maximization within their given } \\
\text { financial framework and expectations of the financial markets (Alexander 2007) }\end{array}$ \\
\hline \multicolumn{2}{|l|}{ Projects } \\
\hline Financial assessment tools & $\begin{array}{l}\text { Companies usually still rely on classical financial parameters and tools for assessing } \\
\text { project portfolios (De Groot et al. 2010; Liesen et al. 2013) }\end{array}$ \\
\hline Sustainability tools & $\begin{array}{l}\text { Quantitative sustainability tools to assess benefits of sustainability are needed, so far } \\
\text { difficult (Epstein and Roy 2001) }\end{array}$ \\
\hline Influential Factor & Influence \\
\hline $\begin{array}{l}\text { Early integration of } \\
\text { sustainability }\end{array}$ & $\begin{array}{l}\text { Sustainability needs to be integrated at the beginning of projects to ensure proactive } \\
\text { targeting of opportunities (Gibson 2006) }\end{array}$ \\
\hline Competition for resources & $\begin{array}{l}\text { Sustainability projects might incur opportunity costs (Haffar and Searcy 2017) which } \\
\text { leads to competition }\end{array}$ \\
\hline \multicolumn{2}{|l|}{ Stakeholder Theory } \\
\hline Definition and ranking & $\begin{array}{l}\text { Companies define their stakeholders; different types of stakeholder influences lead to } \\
\text { different sustainability goals (Sharma and Henriques 2005) }\end{array}$ \\
\hline $\begin{array}{l}\text { Different views on stakeholders } \\
\text { in organization }\end{array}$ & $\begin{array}{l}\text { Individually, stakeholders are viewed in accordance with proximity to respective } \\
\text { business processes and thus may vary significantly on different levels of the organization } \\
\text { (Pedersen 2011) }\end{array}$ \\
\hline $\begin{array}{l}\text { Stakeholders possibly mainly } \\
\text { connected to financials }\end{array}$ & $\begin{array}{l}\text { Companies traditionally tend to mainly value stakeholders that do not decrease } \\
\text { profitability (Varenova et al. 2013) }\end{array}$ \\
\hline \multicolumn{2}{|r|}{ 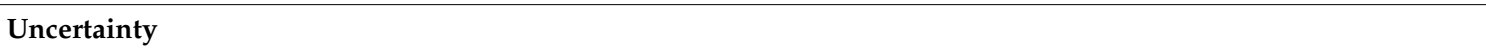 } \\
\hline Handling of uncertainty & $\begin{array}{l}\text { Sustainability projects are long-term in nature and often uncertain, companies and their } \\
\text { managers need to deal with this challenge (Wu and Pagell 2011) }\end{array}$ \\
\hline Cognitive limitations & $\begin{array}{l}\text { Under uncertainty decisions are influenced by cognitive limitations, e.g., heuristics and } \\
\text { biases (Tversky and Kahneman 1974) }\end{array}$ \\
\hline
\end{tabular}




\subsection{Analysis Framework of Influential Factors}

To develop an effective conceptual framework for the previously discussed factors, the optimal boundary conditions must be chosen first. Since the underlying study discusses sustainability in the context of organizations the organizational structure can also be seen as the boundary for the conceptual framework.

The overarching frame is the organization in itself, here an organization is defined by five characteristic features: "social collectivity, organizational and individual goals, coordinating activity, organizational structure and the embedding of the organization within an environment of other organizations" (Miller 2012, p. 12).

Traditionally, these organizations were set up using different hierarchical levels in management (Robbins and Coulter 2016). However, companies are increasingly moving away from employing rigid hierarchical levels and structure their work more and more on project basis (Robbins and Coulter 2016; Hodgson 2004). As such, viewing the organization under the angle of projects can be beneficial in this case. Proceeding on the assumption that work in an organization is often based on projects, the project in itself and the project team delivering on projects can be defined as layers of the framework.

The leadership by top management stays crucial also in project structures. Presently, organizations often use co-management strategies which are responsible for planning and execution of corporate strategies (Wu et al. 2017).

The management of organizations involves different kinds of decisions made at different levels in the organizations. These decisions include strategic, tactical, and operational decisions (Schmidt and Wilhelm 2000). In contrast to tactical and operational decisions, strategic decisions which are long-term in nature often involve high levels of risk, are hard to accurately quantify and have a significant impact on the organization itself. It often involves concepts or goals not clearly predictable by the company yet (Alkaraan 2015). Because key sustainability decisions today are often strategic, they are mainly made at TMT level that represents another important layer of a conceptual framework for sustainability integration.

Having defined the organizational structure (as a boundary), the TMT, the project teams, and projects as appropriate "layers" of a conceptual framework for CS, the relevant influencing factors can be assigned (see Table 1).

The general sustainability drivers, the financial situation and politics on a country level act as influencing factors on the organizational layer as they have an impact affecting the whole organization. Similarly, the factors TMT commitment, long-term view, and functional diversity can be attributed to the top management layer. The condition of following profit maximization acts on the top management as well as the project team layer because it affects people working in an organization. The factors of reliance on financial assessment tools and sustainability assessment tools, early integration of sustainability and competition for resources naturally act on the project layer. Finally, the factors stakeholders and uncertainty should be attributed to all layers associated with people, i.e., the top management and project team layers.

Accordingly, it is possible to develop a framework, as depicted in Figure 2, structuring influential factors on sustainability in organizations. This framework will be used as a basis for the following analysis.

The communication flow on the right side of the framework is for demonstration purposes only. Communication flow is of course much more complex. However, while TMT often determine whether a project is necessary (Slevin and Pinto 1987), they need to authorize projects in order to grant resources at the minimum (Kuster et al. 2011). For simplification purposes, the TMT defines scope and content of projects on a broader basis. 


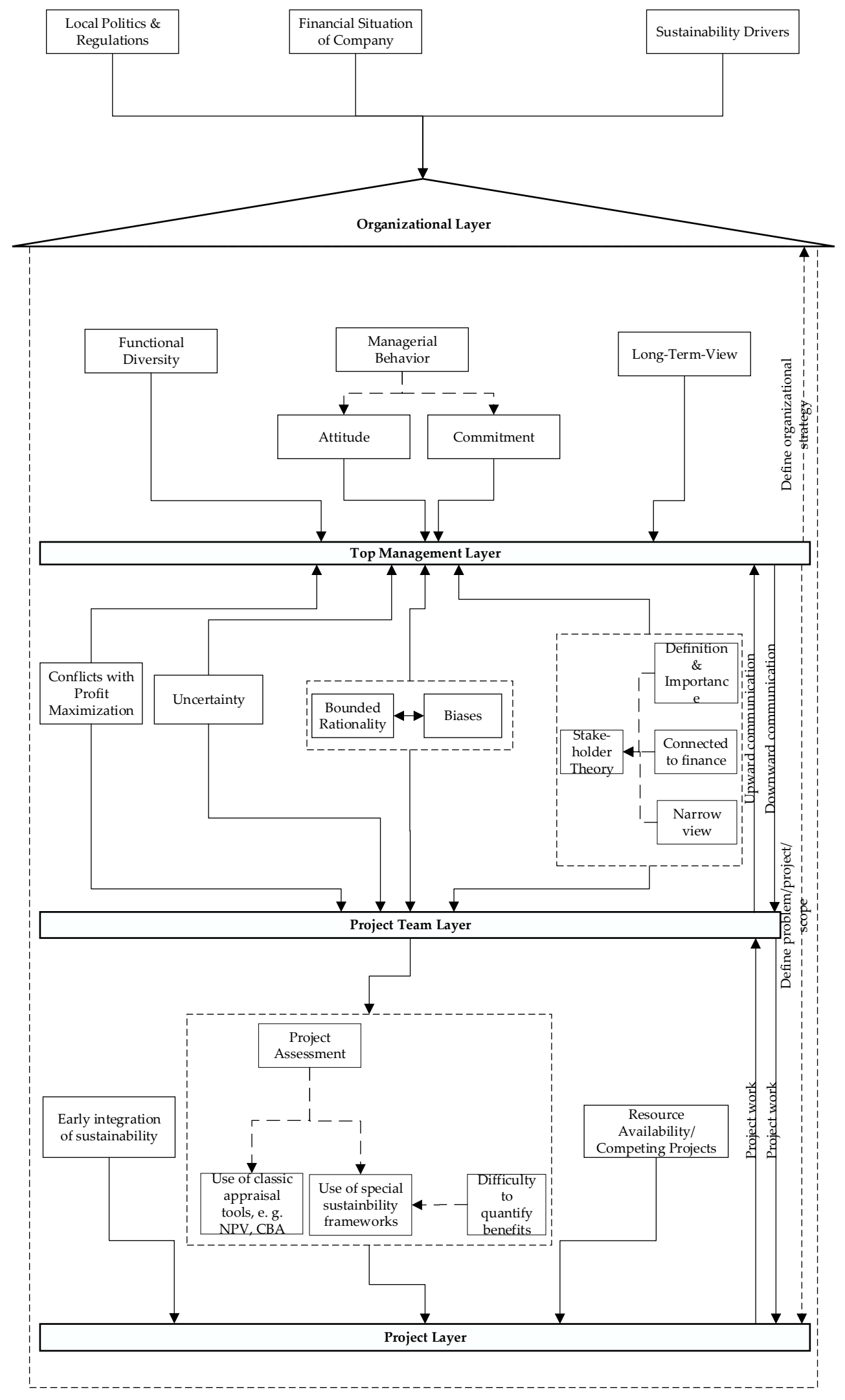

Figure 2. Framework model for the main influential factors on CS in organizations. 


\subsection{Methods}

Considering that, the aim of the underlying study is to explore the perception of influential factors from the point of view of managers acting in an organization, a qualitative approach using semi-structured expert interviews was chosen as methodology. Semi-structured interviews are especially viable if the respondent's viewpoint is analyzed (Blumberg et al. 2014) and can as such be seen as a suitable option in the context of this study and relating to the central research question. For analysis and visualization purposes, a conceptual framework that is common in explorative research, was used.

The first step toward the empirical study was setting up an interview guide based on the outlined theory (see Section 2). The used guide consists of 17 different questions as well as additional sub-questions that are touching on job tasks, sustainability in the company, as well as questions about each framework layer. The full interview guide is listed in the Supplementary Materials.

The main goal of the interviews was therefore examining the perception of these factors in the context of sustainability-profitability tradeoffs and giving first insights into how these are managed.

Interview partners were specifically selected. Viable experts must be able to access privileged information about several key topics in organizations, e.g., decision-making processes (Meuser and Nagel 2009). As such, interview partners were selected so that broad access to information in the context of sustainability was given.

A focus on the chemical industry was chosen because this industry is due to its high energy demand and production of chemical substances very subjugated to sustainability issues and also seen as a success factor by German and European associations (VCI n.d.; Cefic 2019). Similarly, recent trends in the automotive industry also make it a field relevant for sustainability (Sukitsch et al. 2015). Hence, the automotive industry was additionally covered for comparison. Large enterprises were chosen because they are naturally more visible on the political level and have bigger impacts in fields relevant for sustainability (Artiach et al. 2010).

Overall, 14 interviews were held with representatives of multinational companies mainly from the chemical industry but also with two from the automotive industry. Representatives were mainly hailing from Germany, but also in two cases from the Netherlands. During the interviews, methods of Witzel's (2000) "problem-centered interview" were incorporated, e.g., using insights from prior interviews (Witzel 2000). On average, interviews lasted around $60 \mathrm{~min}$.

Evaluation sheets were created in Microsoft Excel. The first evaluation sheet gives basic information about Interviewee ID, Interviewee Name, Company, Name, Date of Interview and Duration (see Table 2).

Table 2. Evaluation sheet 1, basic information on interviews.

\begin{tabular}{ccccc}
\hline Interviewee ID & Interviewee Name & Company Name & Date of Interview & Duration \\
\hline 1 & Thomas Sample & X & 14 August 2019 & $56 \mathrm{~min}$ \\
$\ldots$ & $\ldots$ & $\ldots$ & $\ldots$ & $\ldots$ \\
14 & Robert Muster & $\mathrm{Y}$ & 30 September 2019 & $63 \mathrm{~min}$ \\
\hline
\end{tabular}

Note. Own table.

Basis for the analysis was the audio recording of the interviews and their verbatim transcription. However, frequent filler words were omitted in this case.

The second evaluation sheet (see Table 3) represents the main analysis table of the study. It contains the Interviewee ID according to the first sheet, Question No. and Sub Question according to the interview guide, Answer, Code as well as fields for the Pattern Codes.

In the evaluation sheet (see Table 3) the answers of all interviewees are additionally given as descriptive codes describing the conveyed message and facilitating the analysis of results (Matthew B. Miles and Saldana 2014). Codes were abbreviated. If one code was not sufficient to effectively describe the answer, sub-codes were used. Furthermore, the answers were divided into multiple parts and coded accordingly. Key to effective coding and analysis of the results was a consistent coding for 
which overall around 250 different codes were used. The codes were defined in Evaluation sheet 3 (see Table 4).

Table 3. Evaluation sheet 2, description of interview results.

\begin{tabular}{cccccc}
\hline Interviewee ID & Question No. & Sub Question & Answer & Code & Pattern Code \\
\hline 1 & 1 & & Audio recording/transcription & INNO-EX & EXPERIENCE \\
1 & 7 & a & Audio recording/transcription & SUS-FIN & ECONOMIC \\
$\ldots$ & $\ldots$ & $\ldots$ & Audio recording/transcription & $\ldots$ & \\
$\ldots$ & $\ldots$ & $\ldots$ & Audio recording/transcription & $\ldots$ & \\
14 & 17 & & Audio recording/transcription & $\ldots$ & \\
\hline
\end{tabular}

Note. Own table, codes are examples; around 250 different codes were used to describe the answers.

Table 4. Evaluation sheet 3, meaning of codes.

\begin{tabular}{cc}
\hline Code & Meaning \\
\hline INNO & Innovation \\
$\ldots$ & $\ldots$ \\
SUS & Sustainability \\
\hline \multicolumn{2}{l}{ Note. Own table, codes are examples. }
\end{tabular}

Codes were then adapted in a second round of coding when needed and irrelevant sections were crossed out during this process. Subsequently, pattern coding was applied to the existing coding to find themes and categories (Matthew B. Miles and Saldana 2014), creating the basis for further analysis. Pattern codes were created in accordance with overarching themes. However, in some cases a return to the interview questions helped in identifying possible categories (Matthew B. Miles and Saldana 2014). For each question separate categories were created due to the large differences in the factors discussed. The logic of category identification was described in a separate sheet for each interview question and the logic of pattern coding was double-checked for reliability and validity by a second coder-unfamiliar with the subject matter using question 7a (see the Supplementary Materials) from the interview guide as an example.

\section{Results}

The following section will present the main results from the interviews and will primarily follow the logic of the developed framework and the four layers.

The results will be separated according to industries and highlighted with the help of figures and tables. It should be noted again that responses are mainly from the chemical industry. This gives us a well-founded basis for this industry whereas the two responses from the automotive industry mainly serve as a comparison.

The introductory questions (1-5) aimed at clarifying the position of the interviewee and analyzing the general situation of CS in the respective company while the concluding questions 16 and 17 aimed at getting last feedback on the discussed factors. Detailed results will not be presented here, but can be viewed in the Supplementary Materials (see Tables S1-S3). Generally, the interview partners are holding various sustainability-related functions in their companies. The majority of interview partners confirm that sustainability is both aligned with company strategy and important for top management, but only a minority report on generated competitive advantages from sustainability.

\subsection{Organizational Layer}

The organizational level covers factors that act on a higher level and impact the whole organization (questions 6 and 7).

Question 6 addressed the biggest drivers of sustainability. Several different drivers within the chemical industry were mentioned and are detailed in Figure 3. 


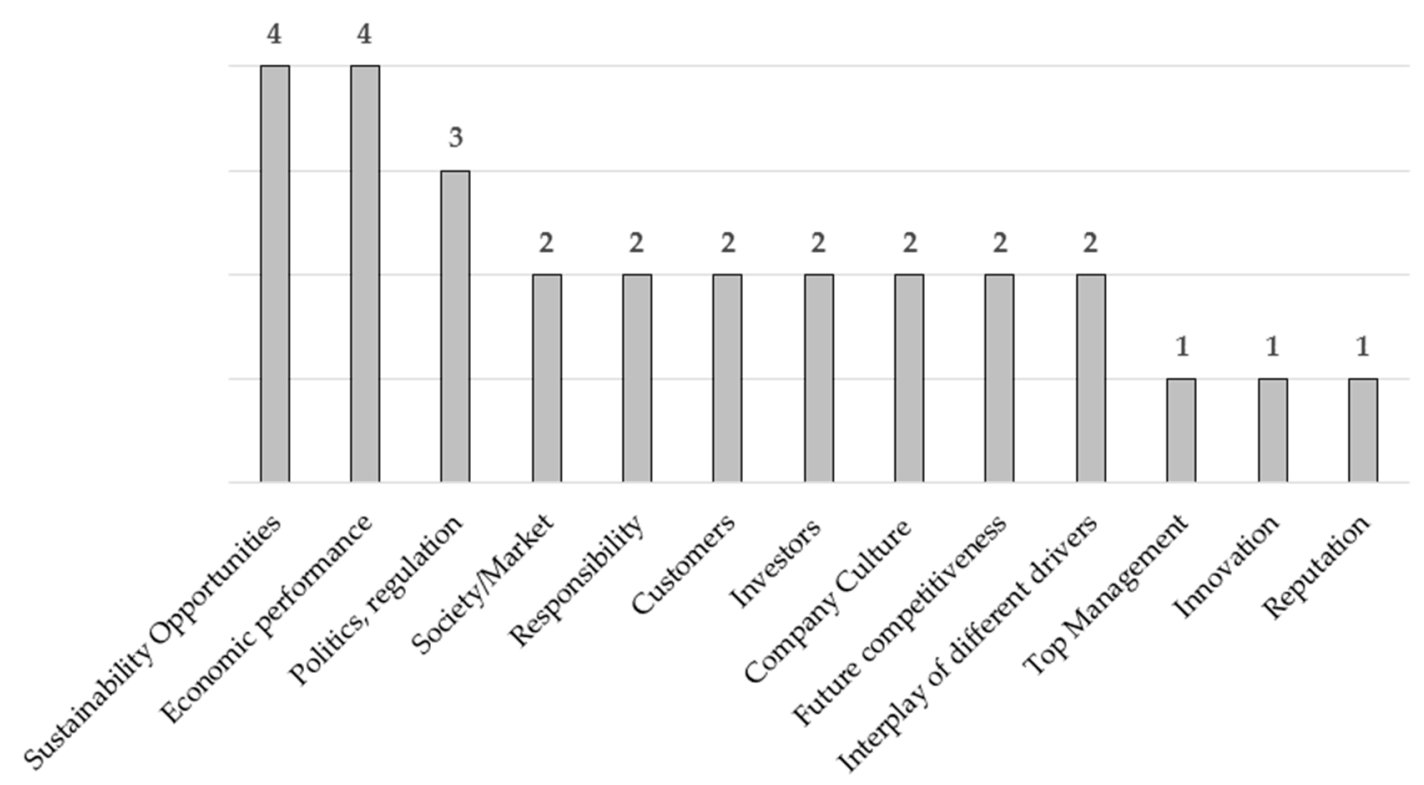

Figure 3. Biggest drivers for sustainability according to interview partners in the chemical industry.

Overall, many drivers for sustainability were mentioned. Meeting sustainability business opportunities and economic performance were mentioned most but only four times overall. Interview partners also mentioned broad conceptual topics such as company culture or responsibility, as well as many other important drivers.

The automotive industry results are shown in Figure 4. Both interviewees see customer demands as the most important drivers.

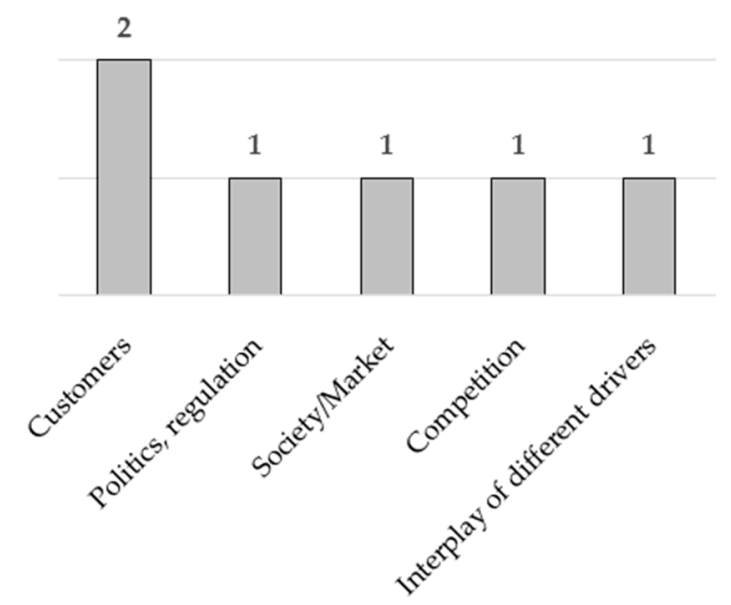

Figure 4. Biggest drivers of sustainability mentioned by two interview partners in the automotive industry.

Question 7 addressed the influence of the financial situation of the company and the influence of local politics or regulatory framework differences on sustainability. Detailed results are presented in Table 5. 
Table 5. Company views on sustainability dependence on financial situation and influence of local politics.

\begin{tabular}{|c|c|c|}
\hline $\begin{array}{l}\text { Chemical } \\
\text { Industry }\end{array}$ & $\begin{array}{l}\text { Dependence on the Financial Situation of } \\
\text { the Company }\end{array}$ & Influence of Local Politics and Regulation \\
\hline Company 1 & No dependence & $\begin{array}{l}\text { Influence, politics have market-correcting possibilities, } \\
\text { e.g., } \mathrm{CO}_{2} \text { certificate trading, governments must } \\
\text { act carefully }\end{array}$ \\
\hline Company 2 & $\begin{array}{l}\text { Dependence, in extreme situations it is } \\
\text { about survival }\end{array}$ & $\begin{array}{l}\text { Small influence on local level, e.g., } \mathrm{CO}_{2} \text { pricing, } \\
\text { governments need to act carefully }\end{array}$ \\
\hline Company 3 & $\begin{array}{l}\text { No dependence, available assets are used in } \\
\text { the best way possible }\end{array}$ & $\begin{array}{l}\text { No influence, no big difference between countries, } \\
\text { apply global strategy }\end{array}$ \\
\hline Company 4 & $\begin{array}{l}\text { Small dependence, especially in the case of } \\
\text { difficult conditions, e.g., competitive markets } \\
\text { with high cost-pressures }\end{array}$ & Influence, some countries have better conditions \\
\hline Company 6 & $\begin{array}{l}\text { No dependence, sustainability depends } \\
\text { on customers }\end{array}$ & $\begin{array}{l}\text { No influence, sustainability gets driven } \\
\text { equally everywhere }\end{array}$ \\
\hline Company 7 & $\begin{array}{l}\text { Small dependence, invest decision might be } \\
\text { adapted, but long-term needs to be kept in } \\
\text { sight, extreme situations might be different }\end{array}$ & No influence, targets need to be reached everywhere \\
\hline Company 9 & $\begin{array}{l}\text { No dependence, sustainability functions as a } \\
\text { decision criterion to decide between projects }\end{array}$ & $\begin{array}{l}\text { No influence, economic concepts might be different, } \\
\text { but the company is looking for sustainability } \\
\text { opportunities everywhere e.g., private company } \\
\text { investments into sustainability in the US }\end{array}$ \\
\hline Company 10 & $\begin{array}{l}\text { Small dependence, in extreme situations it is } \\
\text { about survival }\end{array}$ & $\begin{array}{l}\text { Small influence, local decision-making might be } \\
\text { affected, multinational companies drive global strategy }\end{array}$ \\
\hline Company 11 & No dependence, sustainability has benefits & No influence, global strategy \\
\hline Company 12 & $\begin{array}{l}\text { No dependence, sustainability depends on } \\
\text { customers and is integrated }\end{array}$ & $\begin{array}{l}\text { No influence, global strategy, some countries might } \\
\text { have less strict regulation, but the company still } \\
\text { supplies EU law compliant products }\end{array}$ \\
\hline Company 13 & $\begin{array}{l}\text { Small dependence in the case of projects that } \\
\text { would not be conducted looking at ROI only, } \\
\text { otherwise sustainability is a success factor }\end{array}$ & $\begin{array}{l}\text { Small influence, global strategy but influence on local } \\
\text { decision-making, the company strives to cooperate } \\
\text { with regulators }\end{array}$ \\
\hline Company 14 & No dependence & $\begin{array}{l}\text { Influence, regulation determines where which } \\
\text { processes is implemented first, e.g., due to more } \\
\text { sustainability favorable regulation }\end{array}$ \\
\hline \multicolumn{3}{|l|}{$\begin{array}{l}\text { Automotive } \\
\text { Sector }\end{array}$} \\
\hline Company 5 & $\begin{array}{l}\text { No dependence, both cost reduction and } \\
\text { sustainability are driven right now }\end{array}$ & No influence, global strategy \\
\hline Company 8 & $\begin{array}{l}\text { No dependence, sustainability is a } \\
\text { success factor }\end{array}$ & No influence, global strategy \\
\hline
\end{tabular}

Note. Based on interview results.

Most companies consistently do not perceive a dependence of sustainability on the financial situation of the company. Some argue that sustainability is a core competence and as such, it contributes to company success to a great degree and cannot be ignored even in times of lower economic growth or decline. CS projects should also always be economically attractive.

Companies 4, 7,10, and 13 see a small dependence of sustainability on the financial situation of the company, e.g., for products in very competitive fields or for projects with limited financial return. In these cases, sustainability projects might be discarded due to financial reasons.

Company 2 (similar statements were made by companies 7 and 10) sees a stronger dependence on the financial situation stating that it is hard to take decisions for sustainability when it is about the survival of the company and short-term profits are needed. Company 7 and 10 agree to this.

Regarding the influence of local politics and regulatory frameworks, most companies state that they either see no influence or only small influences on a local level, e.g., in specific local solutions or decision-making. Most companies state that they have global sustainability targets and strategy is 
uniform across countries and outweigh local conditions. The methodology of how each region arrives at their targets might be different due to local conditions.

Company 1, 4, and 14 see an influence of local politics on sustainability. They e.g., state that politics need to act carefully to not tax companies in Europe regarding $\mathrm{CO}_{2}$ too strongly to prevent them from moving to other regions. Company 14 states that new sustainable processes are implemented in favorable regulation frameworks first (see Table 5).

\subsection{Top Management Layer}

The top management level is covered by question 8 (see the Supplementary Materials) with three sub-questions on commitment, functional diversity, and long-term view of top management.

Across industries and interview partners, the awareness for the importance of top management commitment and engagement and its positive impact on sustainability is high.

With respect to functional diversity of top management, almost all interview partners stated that their TMT is functionally diverse. Most companies state that functional diversity has a very positive effect on sustainability because it enables interdisciplinary discussions, is good for innovation and is required for sustainability.

Nonetheless, company 10 and 12 state that while TMT diversity is important eventually it is about the mindset of the people working for the company. Company 12 even gives an example of a sustainable company without functional diversity in the TMT. Furthermore, company 9 states that it is most important how diversity is employed, e.g., by selecting specific people for specific tasks and using different skills to the fullest degree.

Also, nearly all companies (except company 1 ) state that their TMT has a long-term view benefiting sustainability. Companies 7, 9, 10 and 11 explicitly state that both short-term and long-term views need to be balanced.

During the interviews, the factors in Table 6 that influence the long-term perspective of the TMT on sustainability were mentioned.

Table 6. Sources for positive and negative influences on the long-term perspective of a TMT that is necessary for sustainability, according to the interview partners.

\begin{tabular}{ll}
\hline Positive Influence & Negative Influence \\
\hline TMT personality & TMT personality \\
Family ownership & Quarterly pressure \\
Specific company topics targeting the long-term, e.g., purpose & Uncertainty \\
Stable industries & Frequent TMT switches \\
Work culture (regional differences, company) & Work culture (regional differences) \\
Long development processes & Different targets between functions \\
Team decision-making in decision boards & \\
\hline
\end{tabular}

Note. Based on interview results.

\subsection{Project Team Layer}

The project team layer covers the aspect of employees and managers following the principle of profit maximization and how this principle could compromise longer-term sustainability targets. Table 7 shows the interview results on the related question 9 (see the Supplementary Materials).

Overall, companies recognize that seeking profit maximization as a principle can negatively influence sustainability targets and companies and their project teams need to address it.

Interview partners 6 and 10, state that profit maximization and sustainability is not necessarily a contradiction, even in the short-term. Sustainability always must be economical and thus, if the right projects are selected, profitability and sustainability go hand in hand. Similarly, company 1 sees a healthy exchange between profitability and sustainability views that contribute to overall success. 
Table 7. Results of interview question 9 on relevance of profit maximization for sustainability targets and possible responses.

\begin{tabular}{|c|c|c|}
\hline $\begin{array}{l}\text { Chemical } \\
\text { Industry }\end{array}$ & Relevance? & Management of Following Profit Maximization Versus Sustainability \\
\hline Company 1 & No & $\begin{array}{l}\text { Tension forms a healthy exchange; companies cannot make dramatic decisions it is } \\
\text { about balancing }\end{array}$ \\
\hline Company 2 & Yes & Topic is difficult, clear vision is necessary, reexamination every year \\
\hline Company 3 & Yes & $\begin{array}{l}\text { Depends on the case, arguments need to be prepared well, long-term benefits of } \\
\text { sustainability need to be outlined }\end{array}$ \\
\hline Company 4 & Yes & $\begin{array}{l}\text { Depends on the case, trying to establish future estimations of } \mathrm{CO}_{2} \text { and using it } \\
\text { for calculations }\end{array}$ \\
\hline Company 6 & No & Sustainability is also always economical, must be quantified and calculated \\
\hline Company 7 & Yes & $\begin{array}{l}\text { Sustainability has to be integrated into standard processes, so it cannot be } \\
\text { disregarded easily }\end{array}$ \\
\hline Company 9 & Yes & $\begin{array}{l}\text { Sustainability department helps make better decisions, decision-makers in projects } \\
\text { are seeking indicators that are not available in project management yet }\end{array}$ \\
\hline Company 10 & No & $\begin{array}{l}\text { If the right projects are conducted, there is no disagreement, companies must } \\
\text { realize that not everything must be only profit maximization but also integrate } \\
\text { sustainability aspects, sees chemical industry as an enabler }\end{array}$ \\
\hline Company 11 & Yes & Timing of sustainability introductions, e.g., timing of material change is important \\
\hline Company 12 & Yes & Creating evidence for sustainability benefits is important \\
\hline Company 13 & Yes & Top-down communication, management processes \\
\hline Company 14 & Yes & $\begin{array}{l}\text { Company uses scenario work to project the future and establishes respective } \\
\text { project portfolios, also integration of other factors than financial value, e.g., } \\
\mathrm{CO}_{2} \text { and other taxes }\end{array}$ \\
\hline \multicolumn{3}{|l|}{$\begin{array}{l}\text { Automotive } \\
\text { Sector }\end{array}$} \\
\hline Company 5 & Yes & Establish decision boards where target conflicts are discussed \\
\hline Company 8 & Yes & Always difficult, finance department does the balancing \\
\hline
\end{tabular}

\subsection{Project Layer}

The project layer covers questions 10 to 13 (see the Supplementary Materials) and addresses the project assessment and respective tools, timing of integration of sustainability aspects into projects and competition for resources.

Answers to those questions varied to a great degree regarding depth and as such only general results and interesting findings will be presented.

In general, project assessments are done via multiple different criteria of which sustainability aspects are one part. The detailed project assessment process depends on the project and company. In general, it can be said that financial factors are important, as well as meeting different sustainability criteria.

Overall, companies employ classic financial tools such as NPV or CBA to assess financials of a project. Interview partners state that assessing the financial benefits of sustainability is very difficult and companies usually only use calculation methods related to $\mathrm{CO}_{2}$ emissions and energy consumption for which concrete numbers are easier to derive. Interview results varied to a great degree, for detailed results see Table 8 .

The business case of a project in the chemical industry is often not impacted directly but rather through a variety of qualitative sustainability criteria and sustainability assessments to meet boundary conditions and analysis of the specific situation. Companies also often employ sustainability-related portfolio management of at least the innovation portfolio. In the two responses from the automotive industry the business case is not influenced by sustainability in a particular way, but there are efforts to integrate sustainability more in the future. 
Table 8. Results of question 11 related to currently employed project assessment tools, financial assessments of sustainability and the integration of sustainability into business case considerations.

\begin{tabular}{|c|c|c|c|}
\hline $\begin{array}{l}\text { Chemical } \\
\text { Industry }\end{array}$ & Assessment Tool & $\begin{array}{l}\text { Tool to Financially Assess Sustainability } \\
\text { Benefits }\end{array}$ & $\begin{array}{l}\text { Influence of Sustainability on } \\
\text { Business Case }\end{array}$ \\
\hline Company 1 & \multirow{11}{*}{$\begin{array}{l}\text { NPV, Cost-Benefit } \\
\text { Analysis for all } \\
\text { interview } \\
\text { partners }\end{array}$} & Conservative estimation of green margin & $\begin{array}{l}\text { Conservative estimation, different } \\
\text { decision-making, special } \\
\text { considerations }\end{array}$ \\
\hline Company 2 & & $\begin{array}{l}\text { No, there are some projects that are based } \\
\text { on sustainability issues such as circularity }\end{array}$ & $\begin{array}{l}\text { No influence, there are projects } \\
\text { based on sustainability }\end{array}$ \\
\hline Company 3 & & $\begin{array}{l}\text { A tool for innovation projects was } \\
\text { developed and it is worked on to establish } \\
\text { it in other areas, it is very difficult, focus on } \\
\text { easy measurable key performance } \\
\text { indicators (KPI) }\end{array}$ & $\begin{array}{l}\text { Sustainability is additional } \\
\text { criterium, minimum requirements, } \\
\text { portfolio management }\end{array}$ \\
\hline Company 4 & & $\begin{array}{l}\text { No, planning to employ } \mathrm{CO}_{2} \text { future prices } \\
\text { calculations, focus on measurable KPI }\end{array}$ & $\begin{array}{l}\text { Qualitative, soft criteria } \mathrm{CO}_{2}, \\
\text { portfolio management, different } \\
\text { activities, e.g., rating suppliers }\end{array}$ \\
\hline Company 6 & & $\begin{array}{l}\text { No, difficult to do. } \\
\text { Quantify emissions and energy wherever it } \\
\text { makes sense }\end{array}$ & $\begin{array}{l}32 \text { qualitative criteria on } \\
\text { sustainability, quantification of } \mathrm{CO}_{2} \\
\text { emissions or energy where possible, } \\
\text { portfolio management }\end{array}$ \\
\hline Company 7 & & $\begin{array}{l}\text { Difficult to measure, analyze qualitative } \\
\text { benefits on a yearly basis } \\
\mathrm{CO}_{2} \text { price, energy amount }\end{array}$ & $\begin{array}{l}\text { Analysis, yearly product } \\
\text { stewardship analysis to rate } \\
\text { products, } \mathrm{CO}_{2} \text { price, energy amount }\end{array}$ \\
\hline Company 9 & & $\begin{array}{l}\text { Measure customer perception in a tool they } \\
\text { call "Net Promoted System", } \mathrm{CO}_{2} \text { price } \\
\text { assumptions }\end{array}$ & $\begin{array}{l}\text { Integration in all processes, whole } \\
\text { portfolio management, customer } \\
\text { perception analysis, sustainability } \\
\text { opportunities }\end{array}$ \\
\hline Company 10 & & $\begin{array}{l}\text { No, difficult to quantify } \\
\text { Has to be driven uniformly, in the future } \\
\text { calculations will take sustainability benefits } \\
\text { more into account }\end{array}$ & $\begin{array}{l}\text { Analysis of situation, } \\
\text { semi-quantitative point score in } \\
\text { innovation, product specifications } \\
\text { and regulatory requirements in } \\
\text { other operations, portfolio } \\
\text { management }\end{array}$ \\
\hline Company 11 & & $\begin{array}{l}\text { Quantify sustainability benefits, carbon } \\
\text { footprint for portfolio, focus on measurable } \\
\text { KPI }\end{array}$ & $\begin{array}{l}\text { Meeting sustainability boundary } \\
\text { conditions to create something } \\
\text { better, sustainability assessment, } \\
\text { whole portfolio steering, analyze } \\
\text { value chain }\end{array}$ \\
\hline Company 12 & & $\begin{array}{l}\text { No, self-developed sustainability tool has } \\
\text { min. ROI in it }\end{array}$ & $\begin{array}{l}\text { Analysis of situation, e.g., cost } \\
\text { savings downstream, quantification } \\
\text { wherever possible, integration in all } \\
\text { processes }\end{array}$ \\
\hline Company 13 & & $\begin{array}{l}\text { No, sustainability benefits have to be } \\
\text { judged qualitatively, not possible to } \\
\text { quantify }\end{array}$ & $\begin{array}{l}\text { Recognizing problem areas, } \\
\text { estimation of different growth rates, } \\
\mathrm{CO}_{2} \text { calculations for the whole } \\
\text { lifecycle }\end{array}$ \\
\hline Company 14 & $\begin{array}{l}\text { NPV, Cost-Benefit } \\
\text { Analysis }\end{array}$ & $\begin{array}{l}\text { No, but take these things into account } \\
\text { qualitatively, e.g., employee satisfaction } \\
\mathrm{CO}_{2} \text { calculations }\end{array}$ & $\begin{array}{l}\text { Analysis of strategic factors, } \\
\text { quantification wherever possible, } \\
\text { portfolio management, stakeholder } \\
\text { analyses }\end{array}$ \\
\hline \multicolumn{4}{|l|}{$\begin{array}{l}\text { Automotive } \\
\text { Sector }\end{array}$} \\
\hline Company 5 & \multirow{2}{*}{$\begin{array}{l}\text { NPV, Cost-Benefit } \\
\text { Analysis }\end{array}$} & $\begin{array}{l}\text { No, planning to integrate } \mathrm{CO}_{2} \text { prices more } \\
\text { into decision-making as well into } \\
\text { running costs }\end{array}$ & $\begin{array}{l}\text { No influence, planning to put } \\
\text { energy costs into running costs. }\end{array}$ \\
\hline Company 8 & & No & $\begin{array}{l}\text { No influence, but efforts in this } \\
\text { direction }\end{array}$ \\
\hline
\end{tabular}

Note. Based on interview results. 
With respect to competition between sustainability and other projects, interview partners from the chemical industry consistently stated that competition between projects is a general concept and sustainability is not in an especially advantageous or disadvantageous position as sustainability is an integral part of the majority of projects anyway.

Company 9 and 10 state that sustainability considerations facilitate taking better decisions overall. Company 4 states that the importance of sustainability is increasing and a high contribution to sustainability might be the reason for a project to be selected. For companies 9,11 and 12 , sustainability is just a given factor in many projects and interview partner 11 states that the competition is healthy between all projects.

On the other hand, company 8 states that sustainability projects might even be in a favorable position, which was not the case only one year ago.

The last question on the project layer covered the question on whether sustainability considerations are integrated already at the beginning of a project. All companies usually integrate sustainability considerations early in their project management processes. However, there are differences in which projects these considerations are integrated into (see also Table 9). Consensus in the chemical industry is that sustainability aspects are integrated rather early in all projects, whereas for the two examples from the automotive industry this is done for mostly sustainability projects only.

Table 9. Results of question 13 on if and when sustainability aspects are considered in project management processes and for which kind of project.

\begin{tabular}{|c|c|c|}
\hline $\begin{array}{l}\text { Chemical } \\
\text { Industry }\end{array}$ & $\begin{array}{l}\text { Consideration of Sustainability Aspects } \\
\text { in Project Management }\end{array}$ & Which Kind of Project (See Also Question 5) \\
\hline Company 1 & Beginning & All projects \\
\hline Company 2 & No such model for all projects yet & Sustainability projects, efforts to expand \\
\hline Company 3 & Yes, at the beginning for innovation projects & All projects \\
\hline Company 4 & Yes & All projects \\
\hline Company 6 & Yes, at the end of the second stage & All projects \\
\hline Company 7 & No information available & All projects \\
\hline Company 9 & Beginning & All projects \\
\hline Company 10 & Beginning & All projects \\
\hline Company 11 & Beginning & All projects \\
\hline Company 12 & Yes, after the second stage & All projects \\
\hline Company 13 & Beginning & All projects \\
\hline Company 14 & Beginning & No information available \\
\hline \multicolumn{3}{|l|}{$\begin{array}{l}\text { Automotive } \\
\text { Sector }\end{array}$} \\
\hline Company 5 & Beginning & Sustainability projects, efforts to expand \\
\hline Company 8 & Beginning & Sustainability projects, efforts to expand \\
\hline
\end{tabular}

Note. Based on interview results.

\subsection{Superordinate Influences}

Superordinate influences are covered in questions 14 and 15 and address the general concepts of stakeholders and uncertainty. These concepts apply to multiple layers of the framework.

All interview partners are generally aware of the concept of stakeholders and the influence that stakeholders have on the organization. No significant differences between industries were detected. Most companies (9) conduct stakeholder analyses, e.g., materiality analyses to identify key topics and stakeholders. Three interview partners state that stakeholders are project or topic specific.

Regarding stakeholder importance, two companies perform in-depth analyses to identify the most important topics and stakeholders and three other companies do not conduct concrete stakeholder rankings. Another company plans to rate importance in leadership discussions in the future. 
Table 10 gives an overview of received answers on most important stakeholders and their connection to the financial area and of existing different views on stakeholders between top management and other organizational levels (questions $14 \mathrm{~b}$ and $14 \mathrm{c}$ ).

The interview partners mostly state that stakeholders in and outside of the financial area are seen as equally important whereas in the two examples from the automotive industry, stakeholders are connected to the financial area to a greater degree.

There are also no or little differences in how the most important stakeholders are seen by different organizational levels in the company. These small differences could result from the TMT being closer to investors and shareholders, while operational departments are closer to customers, business partners and the external public.

Table 10. Answers to question $14 \mathrm{~b}$ and $14 \mathrm{c}$ on most important company stakeholders, their relevant area and the view of different organizational levels on company stakeholders.

\begin{tabular}{|c|c|c|}
\hline $\begin{array}{l}\text { Chemical } \\
\text { Industry }\end{array}$ & $\begin{array}{l}\text { Relevant Stakeholders (e.g., Mainly } \\
\text { Connected to the Financial Area) }\end{array}$ & $\begin{array}{l}\text { View of Stakeholders on Different } \\
\text { Company Levels }\end{array}$ \\
\hline Company 1 & $\begin{array}{l}\text { All stakeholders equal, stakeholders } \\
\text { securing license to operate are important }\end{array}$ & No difference \\
\hline Company 2 & No information available, & $\begin{array}{l}\text { Small difference, e.g., top management closer to } \\
\text { stakeholders connected to finance }\end{array}$ \\
\hline Company 3 & Situation dependent & $\begin{array}{l}\text { Small difference, e.g., operative areas closer to } \\
\text { markets and customers }\end{array}$ \\
\hline Company 4 & No information available & No difference \\
\hline Company 6 & No information available & No difference, all levels are very customer centric \\
\hline Company 7 & All stakeholders equal & No difference, similar view needs to be present \\
\hline Company 9 & All stakeholders equal & No difference \\
\hline Company 10 & All stakeholders equal & No difference, core view is similar \\
\hline Company 11 & All stakeholders equal & $\begin{array}{l}\text { Small difference, similar on higher level, } \\
\text { but differences to lower level }\end{array}$ \\
\hline Company 12 & No information available & No information available \\
\hline Company 13 & All stakeholders equal & $\begin{array}{l}\text { Small difference, possibly caused by information } \\
\text { deficiencies, employees see the company as } \\
\text { primarily profit focused }\end{array}$ \\
\hline Company 14 & All stakeholders equal & No difference \\
\hline \multicolumn{3}{|l|}{$\begin{array}{l}\text { Automotive } \\
\text { Sector }\end{array}$} \\
\hline Company 5 & $\begin{array}{l}\text { Relatively high finance focus, most } \\
\text { important are shareholders }\end{array}$ & No information available \\
\hline Company 8 & $\begin{array}{l}\text { Relatively high finance focus, customers, } \\
\text { investors, politics }\end{array}$ & No information available \\
\hline
\end{tabular}

Note. Based on interview results.

Interestingly, interview partner 13 states that the majority of employees still consider the company primarily focused on generating profits, while the TMT has recognized sustainability as a success factor. This might result in a higher top-level commitment to sustainability as compared to the whole organization, a difference that has to be addressed and leveled out.

Besides the influence of external stakeholders, uncertainty in decision-making in complex fields is another overarching factor influencing sustainability in companies. Within both industries, uncertainty is a recognized and important topic. Five companies stated that projects with low risks are normally preferred, whereas the other interview partners stated that this is not necessarily the case and uncertain projects are conducted as well.

Both industries, chemical and automotive, work on options to mitigate uncertainty (see Figure 5). Predominantly mentioned were a good balance between lower and higher risk projects as well as defining a long-term strategy with respective long-term strategic objectives. Other efforts include a change in approach by trying to implement a start-up mindset (company 5), adding specific higher risk projects, or efforts to quantify uncertainties e.g., by assuming future $\mathrm{CO}_{2}$ prices (Company 9). 


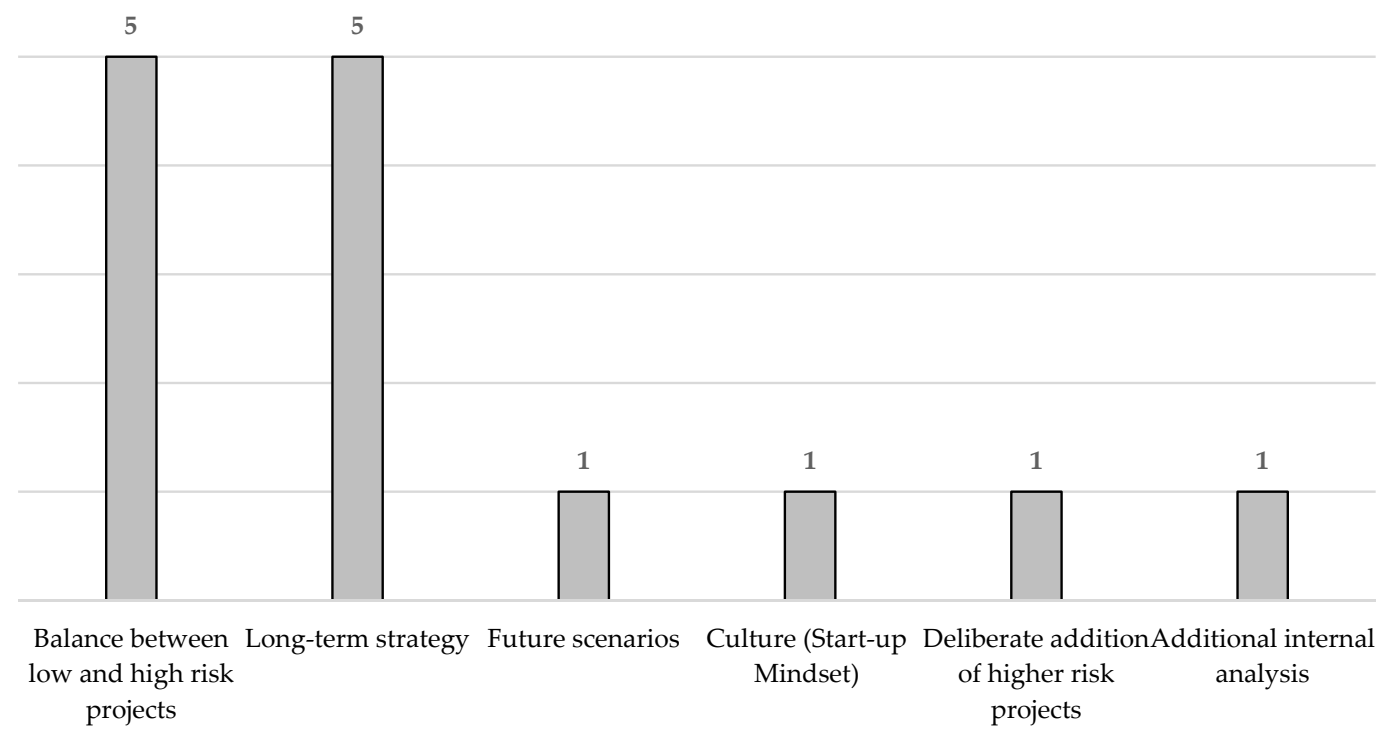

Figure 5. Ways to address uncertainty existing in long-term sustainability efforts.

Initially, there was not a high awareness among the interviewees with respect to cognitive limitations and biases under uncertainty. After mentioning the status quo bias (preference for the current state under uncertainty) during the interview, three interview partners state that management is generally aware of this bias. In most cases, more detailed discussions revealed that in fact several measures are already in place to overcome cognitive biases (see Figure 6).

Management skills and teamwork are mentioned as most important mitigation factors for uncertainty and were mentioned as countermeasures to cognitive limitations in general and the status quo bias specifically.

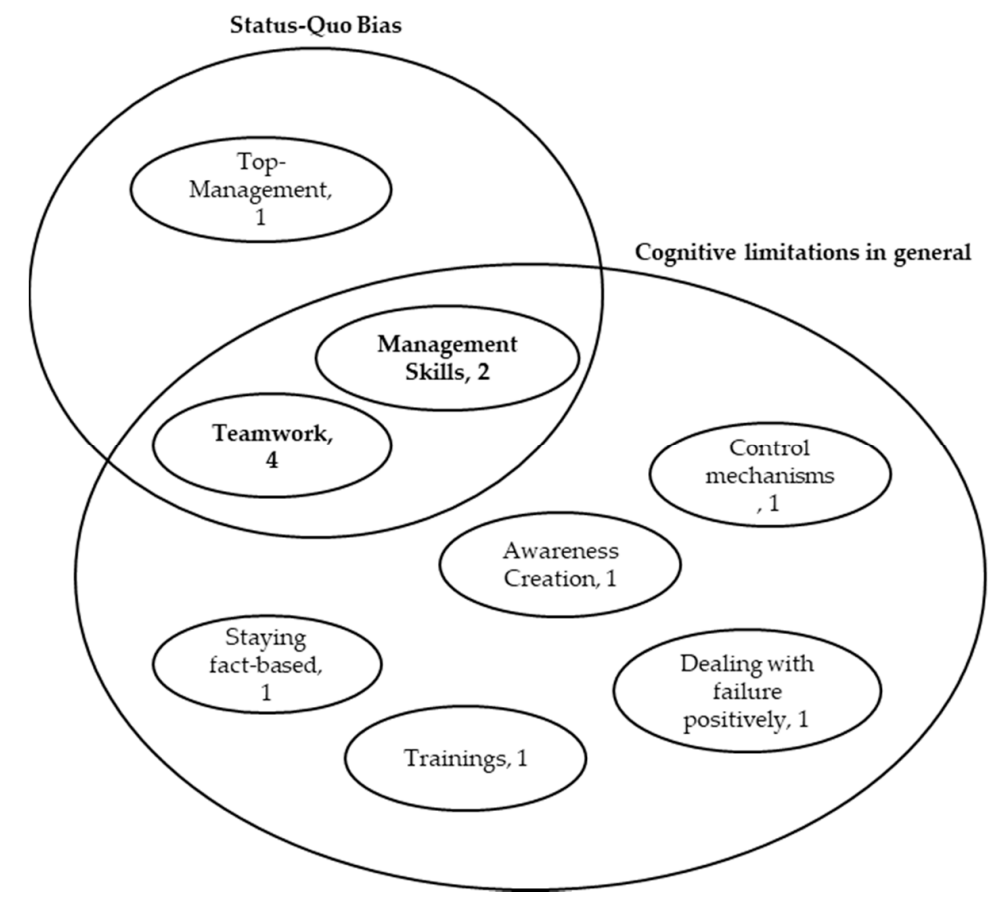

Figure 6. Interview partners response on countermeasures to overcome the status quo bias and cognitive limitations in general, number indicates quantity. 


\section{Discussion}

Purpose of this study was to gain insights into the perception of relevant influential factors on sustainability and related decision-making in organizations. The interviewed sustainability managers confirmed that all factors identified in the previous sections were relevant and only very few additional factors were suggested. The following section will focus on the discussion of the interview results while keeping in mind limitations of this study and give suggestions for future research opportunities.

The discussion of the findings from Section 4 with existing literature will mainly focus on the organizational, the project team and project layer within the framework, as well as discuss how companies are viewing and dealing with uncertainty as a relevant superordinate influence.

Influential factors like top management, cognitive limitations in general and stakeholders are identified as relevant topics in the context of sustainability also by the interview partners. These topics, however, already have a vast theoretical background and in most areas, results do not indicate new findings beyond information already contained in the literature. Table 11 gives an overview of the responses on these factors that will not be discussed in detail here.

Table 11. Summary of influential factors that will not be discussed in further detail in the text as results are mostly in line with literature findings.

\begin{tabular}{llll}
\hline $\begin{array}{l}\text { Influential } \\
\text { Factor }\end{array}$ & Findings in the Literature & Interview Results & Insights \\
\hline Top Management & $\begin{array}{l}\text { engagement and } \\
\text { commitment of TMT is } \\
\text { very important (Walker } \\
\text { et al. 2015) }\end{array}$ & $\begin{array}{l}\text { TMT plays a vital role } \\
\text { for interviewees }\end{array}$ & $-\begin{array}{l}\text { in line with theory, companies see TMT } \\
\text { as a very important factor } \\
\text { fommitment }\end{array}$
\end{tabular}

\begin{tabular}{|c|c|c|c|c|c|c|}
\hline $\begin{array}{l}\text { Functional } \\
\text { diversity }\end{array}$ & - & $\begin{array}{l}\text { functionally diverse } \\
\text { TMTs contribute to a } \\
\text { greater CSP (Henry et } \\
\text { al. 2019) }\end{array}$ & - & $\begin{array}{l}\text { most have functional diverse } \\
\text { TMTs, see it as positive } \\
\text { for sustainability } \\
\text { diversity is } \\
\text { generally important } \\
\text { mindset is also important } \\
\text { diversity needs to be } \\
\text { used well }\end{array}$ & - & $\begin{array}{l}\text { companies also perceive a positive } \\
\text { influence from functional diverse TMT } \\
\text { often extend this to diversity, implying } \\
\text { that e.g., gender diversity could be } \\
\text { positive as well } \\
\text { mindset of organizations as key factor }\end{array}$ \\
\hline $\begin{array}{l}\text { Long-term } \\
\text { perspective }\end{array}$ & - & $\begin{array}{l}\text { a long-term } \\
\text { perspective is needed } \\
\text { (Bansal and DesJardine } \\
2014 \text { ) } \\
\text { viewing both long and } \\
\text { short-term } \\
\text { perspectives important } \\
\text { (Hörisch et al. 2014) }\end{array}$ & - & $\begin{array}{l}\text { interview partners state their } \\
\text { TMT has a } \\
\text { long-term perspective } \\
\text { four explicitly state that both } \\
\text { perspectives are needed } \\
\text { mention positive and } \\
\text { negative influences on } \\
\text { long-term perspective }\end{array}$ & - & $\begin{array}{l}\text { companies have recognized that } \\
\text { sustainability is a long-term topic } \\
\text { In line with theory, four state that both } \\
\text { perspectives are important } \\
\text { possible contribution in factors that } \\
\text { influence perspective of TMT }\end{array}$ \\
\hline \multicolumn{7}{|l|}{ Projects } \\
\hline $\begin{array}{l}\text { Competition } \\
\text { for resources }\end{array}$ & - & $\begin{array}{l}\text { sustainability is in } \\
\text { competition for } \\
\text { resources with other } \\
\text { projects (Teng et al. } \\
\text { 2014) }\end{array}$ & - & $\begin{array}{l}\text { competition is a } \\
\text { general concept } \\
\text { sustainability facilitates } \\
\text { selecting the best projects }\end{array}$ & - & $\begin{array}{l}\text { project competition can mostly not be } \\
\text { seen as an influential factor, since } \\
\text { sustainability often is a part of projects, } \\
\text { not an own project }\end{array}$ \\
\hline $\begin{array}{l}\text { Early } \\
\text { integration of } \\
\text { sustainability }\end{array}$ & - & $\begin{array}{l}\text { early integration of } \\
\text { sustainability allows } \\
\text { for proactive targeting } \\
\text { of opportunities } \\
\text { (Gibson 2006) }\end{array}$ & & $\begin{array}{l}\text { companies usually consider } \\
\text { sustainability early on } \\
\text { sometimes only in } \\
\text { sustainability projects } \\
\text { (examples in the } \\
\text { automotive industry) }\end{array}$ & - & $\begin{array}{l}\text { companies have recognized that } \\
\text { sustainability needs to be part of an } \\
\text { early project assessment } \\
\text {-strive to integrate sustainability in all } \\
\text { projects at the beginning }\end{array}$ \\
\hline
\end{tabular}


Table 11. Cont.

\begin{tabular}{|c|c|c|c|}
\hline $\begin{array}{l}\text { Influential } \\
\text { Factor }\end{array}$ & Findings in the Literature & Interview Results & Insights \\
\hline \multicolumn{4}{|c|}{ Stakeholder Theory } \\
\hline $\begin{array}{l}\text { Definition } \\
\text { and ranking }\end{array}$ & $\begin{array}{l}\text { - } \quad \text { influence of } \\
\text { stakeholders varies } \\
\text { depending on } \\
\text { stakeholder definition } \\
\text { (Sharma and } \\
\text { Henriques 2005) }\end{array}$ & $\begin{array}{ll}\text { - } & \text { usually stakeholder analyses } \\
\text { are conducted } \\
\text { - } & \text { stakeholder ranking } \\
\text { is common } \\
\text { - } \quad \text { relevant stakeholders often } \\
\text { depend on topic/project }\end{array}$ & $\begin{array}{l}\text { - as a general concept stakeholder theory } \\
\text { plays a crucial role, this is proven by a } \\
\text { regular stakeholder analyses } \\
\text { in companies }\end{array}$ \\
\hline $\begin{array}{l}\text { Different } \\
\text { views on } \\
\text { stakeholders } \\
\text { in } \\
\text { organization }\end{array}$ & $\begin{array}{l}\text { - } \\
\text { stakeholders are } \\
\text { individually defined } \\
\text { according to most } \\
\text { relevant business } \\
\text { processes (Pedersen } \\
\text { 2011) }\end{array}$ & $\begin{array}{l}\text { - } \quad \text { interview partners only see a } \\
\text { small difference } \\
\text { throughout organization } \\
\text { - } \quad \text { communication deficit } \\
\text { between TMT and } \\
\text { employees for one company }\end{array}$ & $\begin{array}{l}\text { - in line with theory there might be a } \\
\text { difference between employees who are } \\
\text { closer to communities and customers } \\
\text { and the TMT who is closer } \\
\text { to shareholders } \\
\text { - } \quad \text { influence of these difference on } \\
\text { sustainability seems small } \\
\text { - } \\
\text { possible influence of } \\
\text { communication deficit }\end{array}$ \\
\hline $\begin{array}{l}\text { Stakeholders } \\
\text { possibly } \\
\text { mainly } \\
\text { connected to } \\
\text { financials }\end{array}$ & $\begin{array}{l}\text { companies have a } \\
\text { narrow view of } \\
\text { stakeholders, mainly } \\
\text { integrate those that do } \\
\text { not compromise their } \\
\text { profitability (Varenova } \\
\text { et al. 2013) }\end{array}$ & $\begin{array}{l}\text { - } \\
\text { such as shareholders or } \\
\text { customers are important but } \\
\text { not only them } \\
\text { - } \quad \text { all stakeholders must be } \\
\text { targeted, or else } \\
\text { business fails } \\
\text { examples from the } \\
\text { automotive industry with } \\
\text { high focus on } \\
\text { commercial stakeholders }\end{array}$ & $\begin{array}{l}\text { - } \\
\text { and potential difference between industries } \\
\text { sustainability, possibly explained by the } \\
\text { chemical industry being close to } \\
\text { environmental stakeholders for a } \\
\text { longer time } \\
\text { stakeholders are becoming more equal } \\
\text { as a result of sustainability }\end{array}$ \\
\hline $\begin{array}{l}\text { Cognitive } \\
\text { limitations }\end{array}$ & $\begin{array}{l}\text { - } \quad \text { various cognitive } \\
\text { limitations influence } \\
\text { decision-making under } \\
\text { uncertainty (Tversky } \\
\text { and Kahneman 1974) } \\
\text { managers are acting } \\
\text { under bounded } \\
\text { rationality when } \\
\text { managing } \\
\text { sustainability (Walker } \\
\text { et al. 2014) }\end{array}$ & $\begin{array}{l}\text { - } \\
\text { aw general, not a high } \\
\text { awareness of cognitive } \\
\text { limitations among } \\
\text { interviewees without } \\
\text { further explanation } \\
\text { - } \quad \text { status quo bias mentioned in } \\
\text { connection } \\
\text { with sustainability } \\
\text { - } \quad \text { other biases seen as possibly } \\
\text { relevant as well } \\
\text { Give examples of some } \\
\text { measures that are in place }\end{array}$ & 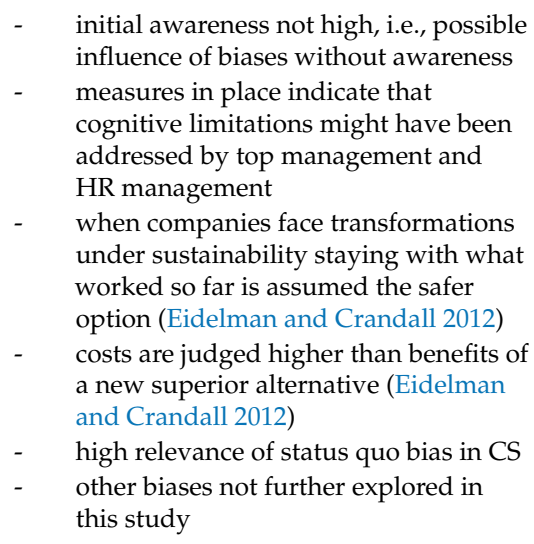 \\
\hline
\end{tabular}

Note. Based on interview results and theoretic background.

Initial interview questions analyzed the integration of sustainability in the companies of the interview partners. Results suggest that the chemical industry has already developed a strong focus on sustainability with well-established sustainability processes. Possibly, the long-term experience with focused safety, health and environmental management has supported this development (Darkow and Heiko 2013).

As response to questions on relevant sustainability drivers a multitude of important drivers was mentioned. In line with theory, the external drivers, customers, investors, and politics were mentioned frequently as important drivers (Lozano 2015). Interview partners in the chemical industry, however, frequently mention internal drivers as most important for their companies. Theory states that internal 
drivers elicit a more proactive view on CS (Lozano 2015) suggesting that the chemical industry takes a more proactive stance on CS in comparison to the other industries which mainly consider external drivers (see examples from the automotive industry in this study). This can be also linked to the chemical industry in general facing strict government regulations, for example in the area of safety in large scale chemical production which has been a crucial topic and "license to operate" for the chemical industry for decades and will continue to be critical (Darkow and Heiko 2013). On the other hand, the automotive industry has just recently been faced with stricter government regulation in the wake of the transition to electric mobility (Verband der Automobilindustrie 2018). Theory suggests that once companies learned to keep up with regulations, the approach to CS becomes more proactive (Nidumolu et al. 2009). This suggests that the chemical industry has become used to keeping up with regulation. Overall, external and internal drivers are highly important for sustainability in companies, but awareness and priorities seem to vary between industries.

Remarkably, the interview partners' consensus is that sustainability does not critically depend on the financial situation the company is facing which is in contrast to theory which suggests a positive correlation between CSP and profitability (Margolis et al. 2011; Artiach et al. 2010). Companies in general state that in times of high profitability, companies continue investing into the most beneficial projects, while even in times of lower profitability sustainability is still seen as a success factor. Only two companies see disadvantages for sustainability projects in the case of very competitive markets and very high cost-pressure making further investments difficult and in the case of projects which are less optimal only looking at ROI.

This finding suggests that sustainability might have evolved as a core concept in industrial practice that is not compromised on even in times of less profitability.

Political frameworks in general are seen as an influential factor by the interview partners in line with theory. The mainly in Europe headquartered companies however mostly state that local political conditions only have a small influence on decision-making for sustainability as a global concept. One of the three companies suggesting a higher influence of local politics is from the Middle East, possibly suggesting that this might be viewed differently by companies headquartered in other regions and having their main assets there. Europe is a leader on environmental law with stringent policies in place (Kelemen and Knievel 2015). As such, European companies are accustomed to these policies and comply with European law globally.

Another factor discussed with the interview partners were possible conflicts between short-term profit expectations and long-term sustainability targets which might hinder the implementation of sustainability projects (Alexander 2007). Most interview partners mentioned this factor as relevant where two interviewees stated that when only the right projects are chosen this conflict would disappear.

To reconcile the compromise between short-term profitability and sustainability, theory suggests changing the selection criteria of projects to a more integrative view on environmental and social aspects (Alexander 2007). Interestingly, the interviewed companies rating sustainability in generally very high do not yet mention that environmental or social dimensions for projects have been elevated on par with financial value.

The primary goal of companies is still generating profit, but many companies have developed several at least qualitative methods to integrate sustainability in an increasing variety of business processes. Furthermore, it is important to show long-term sustainability-related benefits being greater than short-term value. In this respect, an interesting factor mentioned by one interview is the importance of timing of sustainability projects to be closely linked to financial considerations. Researching the timing of integration of sustainability into financial frameworks could be an important contribution further progressing in the field of sustainability.

Dealing with uncertainty is perceived as an important topic by managers in the context of sustainability, its influence being evident by companies preferring certain projects over uncertain ones. Initiatives that have a high impact on CS tend to be longer-term and thus more uncertain in nature, 
interview partner 12 even calls it "bets on the future". In line with theory, decision-making is more difficult in such long-term cases (Retief et al. 2013).

According to theory, the most obvious choice in coping with uncertainty lies in gathering additional data (Lipshitz and Strauss 1997). However, only interview partner 7 suggests this solution for sustainability. In contrast, it is argued that the data collection approach for sustainability is very resource intensive and needs to be selected well. In general, gathering additional data might not be the ideal method of reducing uncertainty in the context of CS, as the field itself and related uncertainties might be broader than in other projects. Any effort in data collection for CS must be well planned, focused and fit to the setup and direction of the company.

Companies most often mention a necessary balance between low-risk and high-risk projects and a long-term strategy (see Figure 5). In theory, employing risk management to balance projects is crucial (Olsson 2008). For example, Collis (1992) recommends four distinct approaches to handling uncertainty of which one approach is the "Insurance" approach, committing resources to multiple investments that would together bring a return under all possible outcomes (Collis 1992). Results suggest that companies are in general certain that CS is increasing in importance and align their project portfolios according to sustainability. However, they are generally not sure in what way exactly and how fast sustainability developments will occur due to the high number of external contingencies. As such, companies indeed seem to take an "Insurance" approach in managing their project portfolios. This is also in line with interviewees stating that defining a long-term strategy is vital in managing uncertainty. Companies have recognized that sustainability will become a major factor for their business, but not yet how exactly and when they will be impacted.

In this regard, also prediction can play an important role, especially if it is founded on a realistic understanding of the future (Collis 1992). Company 9, e.g., uses this approach by making assumptions on future $\mathrm{CO}_{2}$ prices in different time-horizon projects and scenarios.

Uncertainty is also always present in transformations (Perminova et al. 2008). Therefore, companies that are under (sustainability) transformations have to deal with uncertainties. Dealing with uncertainty is a key element of the sustainability management that must be accounted for during the setting of overall priorities but also on a lower working level, e.g., during project assessments.

In line with theory, companies are mainly still using classic financial appraisal tools. They state that quantifying sustainability benefits remains difficult and a challenge. Calculations in this area are mostly based on measurable factors such as $\mathrm{CO}_{2}$ emission and energy consumption (see Table 8). However, these factors are closely related to costs. In contrast there are benefits such as increased talent hiring, chances for higher margins, higher employee productivity that might be sustainability-related but are not accounted for in company business cases as of now. Companies increasingly recognize that sustainability benefits such as increased customer loyalty or reputation exist (Aragon-Correa et al. 2017) and do play a role for their business.

Theory has outlined the need for new tools for assessing such business cases (Epstein and Wisner 2001). In interviewed companies the business case is mostly influenced through a non-financial sustainability-related analysis, e.g., by product or product portfolio assessments or supplier reviews. Noteworthy to mention is that company 12 states that financial benefits of sustainability while complex can be measured and integrated into the business case, e.g., as energy cost or downstream savings; however, they still do not take employee satisfaction and similar factors into account in a financial way.

Business cases for sustainability have to be created and stronger links between ecological, social value and financial value established (Schaltegger et al. 2012). Business must see CS as an opportunity with wide ranging benefits but must be able to communicate these cases effectively in the form of financial benefits to decision-makers. Companies are increasingly moving into this direction, especially in the chemical industry. Achieving a stronger link between sustainability and financials could substantially contribute to decreasing uncertainty of CS. How to achieve this best should be a topic of further research and is likely industry dependent. A study in the Brazilian beef industry was able to 
link qualitative benefits to a monetary value and could be an impulse for further research (Whelan et al. 2017) and application in other industries.

One topic spanning multiple questions is the possible different status or perception between industries, for example in the case of drivers, stakeholder focus, the influence on business case, or in which projects sustainability considerations get integrated. This effect is not necessarily related to the industry itself but can rather be traced back to CSP where we see the chemical industry as a frontrunner based on the feedback we received on the introductory questions. This is also demonstrated by a great percentage of interviewed chemical companies represented in the FTSE4GOOD Europe index (FTSE Russell n.d.). Furthermore, company 10 even states that the chemical industry has the role of an "enabler" that enables sustainable solutions in other market segments (see Table 7, company 10).

Based on the input from the interview partners it is also possible to expand the initial conceptual framework (see Figure 2) into the modified framework depicted in Figure 7. The red squares indicate additional suggestions from the interview partners (Table S3). The modified framework contains changes on organizational layer but also regarding counteracting on uncertainty of the project teams and project assessments. These changes show that sustainability integration and decision-making in industry has evolved beyond a theoretical approach and entered industrial practice.

Although it is very difficult to ascertain the relative strength of each factor it can be stated that interview partners find the top management layer and the organizational layer as most influential, which makes sense since the interplay of both sets the strategic course of the company.

The adapted framework gives further input for managerial application. It is possible to identify key topics and focus points relevant when managing CS in practice. The outlined dependencies might give valid information for CS strategy and the status of individual factors reflects current state and development of CS management. The following success factors for CS derived from results, discussion and theory can be outlined:

- $\quad$ Leading companies see CS from an opportunity's perspective

- Sustainability needs to be a part of all business processes; the whole organization needs to be committed to and comfortable with CS including all employees

- CS needs to be tangible, expressed in concrete KPIs ideally with a direct connection to financials but also in the mind of people, e.g., comfortability with change

- Sustainability as a vital component of company strategy, even in times of economic downturn or lower profitability

- Managing the uncertainty surrounding long-term CS strategies by creating awareness and driving quantification in management processes is important

- Application of a holistic approach to CS

The developed framework can also give directions for managers especially in an early stage of CS. Companies in this study have already advanced in integrating sustainability in industrial practice.

Like any study, this study has inherent limitations. Firstly, overall completeness of the framework cannot be ensured since no completeness check was conducted in the literature search.

Moreover, as interview partners mainly come from large chemical companies, the results are relevant for this industry. The chemical industry seems highly influenced by sustainability considerations and to be a frontrunner in CS. The two interviews with the automotive industry give indications but are too few to allow for a comparison between industries. An extension of this study to other industries and smaller chemical companies (in comparison to the large companies interviewed in this study) is recommended.

Moreover, it was not possible to ensure that all interview partners held similar positions, which might contribute to an individually different perception of factors. In addition, due to the limited sample size results are not representative for complex organizational topics such as corporate sustainability. 


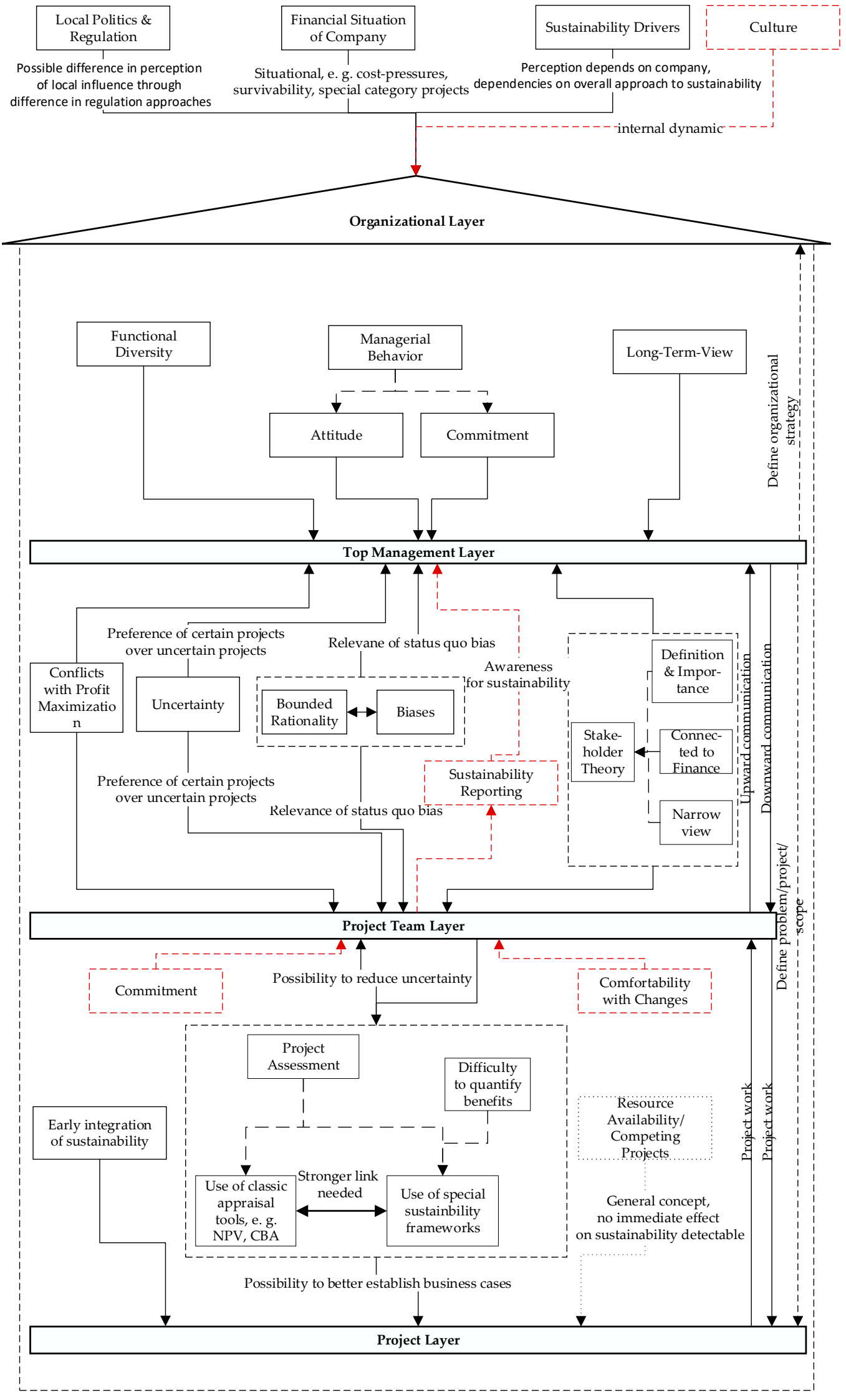

Figure 7. Adapted framework after integrating interview results and conclusions. 
Furthermore, the topic of CS is a much-researched topic and ensuring completeness of all relevant factors is almost impossible. Although the most relevant factors have been identified, it is likely that still additional factors exist (or might come up in the future) in the literature that was not discovered here. A continuous monitoring of influencing factors on sustainability in the literature is mandatory for this complex field.

Furthermore, the underlying study did not deal with any form of quantitative measurement of sustainable value in organizations. As such, a concrete number to compare between companies and industries is missing.

Another limitation is that the underlying study focused on the organization and business of a company from a project perspective. While results indicate that project structures are increasingly important, the analysis should still be applied also to non-project-based business processes with some interviewees even indicating that existing operations are also important.

The study identified some important avenues for research. As stated above, research should be expanded to cover the limitations in industry, company size and integrate the perspective of standard operations as well as investigate the suggestions by interview partners (marked red in Figure 7). Especially interesting would be a full comparison to an industry with a lower CSP and establish learnings for less sustainable companies as well as avenues for improvement. Furthermore, expanding upon the qualitative results would be a quantitative study further cementing the role of the identified factors.

This study entails the discussion of which factors impact CS; however, it does not deal with concrete decision-making, which would ideally complement the existing framework as an additional layer or spanning through all layers. Researching this topic and integrating it into the framework would make for a substantial contribution to the framework and expand its managerial use significantly.

\section{Conclusions}

This study applies a holistic view on influential factors on sustainability in organizations using a framework approach aiming at analyzing how managers in industrial companies view key influential factors on sustainability. Previous literature was lacking a comprehensive and integrative view of sustainability in organizations linking all influential factors in a framework.

Regarding the research question on how managers and companies perceive key influential factors on sustainability, no simple answer can be given. There seems to be little disagreement between the interviewed companies about the relevance of identified influential factors. Although weight and relevance of the factors vary between companies influences on the organizational and top management layer stand out in terms of impact on sustainability. Moreover, this study was able to establish links between influential factors and its effect on framework layers. For example, on the organizational layer, the study revealed that the financial situation of the company is only relevant in very competitive markets, and that the influence of local regulation and perception of main sustainability drivers can depend on the geographic region and approach to CS, respectively.

Furthermore, perception of influential factors can be different between industries. This could trace back to the underlying CSP. The introductory questions suggest that overall sustainability seems to be a highly important topic in the chemical industry. Frontrunners have recognized that sustainability needs to play a role in all projects and stakeholders beyond the financial area need to be addressed. Furthermore, the perception of factors can of course vary between companies of the same industry.

One of the key topics identified in the context of sustainability is the management of uncertainty. Inherent to sustainability is its long-term scope and uncertainty which company 12 even calls "bets on the future". There must be measures in place to mitigate uncertainty. In this regard, companies are currently lacking concrete KPIs to measure the benefits of sustainability and employ mostly qualitative tools or calculations for easily measurable KPIs for $\mathrm{CO}_{2}$ and energy usage to create business cases. There is potential in using more quantitative methods to better connect ecological and social value to 
classic financial value in order to reduce uncertainty and create business cases for sustainability that public companies need to advance their sustainability efforts.

In the context of this study, two contributions can be made. First, a framework was established and after the interviews expanded which underlines the importance of the influential factors in practice and provides necessary focal points for CS managers. In addition, the analysis of the results of the interviews provides helpful insights into the actual status and direction of sustainability management in multinational companies. In particular, for new sustainability managers the framework can give direction for the orientation of sustainability management and give indications which factors need to be addressed early and how they interrelate with each other.

Overall, sustainability and factors influencing it are becoming increasingly important for today's business world as proven by the high perceived relevance of the influential factors for the interview partners. It is likely that perception and relevance of these factors will significantly broaden, gain further weight and continue to evolve together with further integration of sustainability as a business driver in organizations.

Supplementary Materials: The following are available online at http://www.mdpi.com/2076-3387/10/3/63/s1.

Funding: This research received no external funding.

Conflicts of Interest: The authors declare no conflict of interest.

\section{References}

Alberti, Fernando G., and Mario A. Varon Garrido. 2017. Can profit and sustainability goals co-exist? New business models for hybrid firms. Journal of Business Strategy 8: 3-13. [CrossRef]

Alexander, John. 2007. Environmental Sustainability versus Profit Maximization: Overcoming Systemic Constraints on Implementing Normatively Preferable Alternatives. Journal of Business Ethics 76: 155-62. [CrossRef]

Alexander, Anthony, Helen Walker, and Mohamed Naim. 2014. Decision theory in sustainable supply chain management: A literature review. Supply Chain Management 19: 504-22. [CrossRef]

Alkaraan, Fadi. 2015. Strategic Investment Decision-Making Perspectives. Advances in Mergers and Acquisitions 14: 53-66.

Aragon-Correa, J. Alberto, Alfred A. Marcus, Jorge E. Rivera, and Amy L. Kenworthy. 2017. Sustainability Management Teaching Resources and the Challenge of Balancing Planet, People, and Profits. Academy of Management Learning \& Education 16: 469-83.

Artiach, Tracy, Darren Lee, David Nelson, and Julie Walker. 2010. The determinants of corporate sustainability performance. Accounting \& Finance 50: 31-51.

Ball, Daniel R. 2011. Integrating Multiple Sustainability Criteria in Technology, Innovation, and Operations Management Strategic Decisions. Paper presented at the Northeast Business \& Economics Association, Philadelphia, PA, USA, November 3-5; pp. 27-33.

Bansal, Pratima, and Mark R. DesJardine. 2014. Business sustainability: It is about time. Strategic Organization 12: 70-78. [CrossRef]

Baumgartner, Rupert J. 2009. Organizational culture and leadership: Preconditions for the development of a sustainable corporation. Sustainable Development 17: 102-13. [CrossRef]

Beckmann, Markus, Stefan Hielscher, and Ingo Pies. 2014. Commitment Strategies for Sustainability: How Business Firms Can Transform Trade-Offs Into Win-Win Outcomes. Business Strategy and the Environment 23: 18-37. [CrossRef]

Berns, M., A. Townsend, Z. Khayat, B. Balagopal, M. Reeves, M. S. Hopkins, and N. Kruschwitz. 2009. Sustainability and Competitive Advantage. MIT Sloan Management Review 51: 18-26.

Berns, Maurice, Andrew Townend, Zayna Khayat, Balu Balagopal, Martin Reeves, Michael S. Hopkins, and Nina Kruschwitz. 2009. The Business of Sustainability. MIT Sloan Management Review 51: 20-26. Available online: https://sloanreview.mit.edu/projects/the-business-of-sustainability/ (accessed on 13 November 2019).

Blumberg, Boris F., Donald. R. Cooper, and Pamela S. Schindler. 2014. Business Research Methods, 4th ed. Berkshire: McGraw Hill High Education. 
Bodhanwala, Shernaz, and Ruzbeh Bodhanwala. 2018. Does corporate sustainability impact firm profitability? Evidence from India. Management Decision 56: 1734-47. [CrossRef]

Brundtland, G. H. 1987. Report of the World Commission on Environment and Development: Our Common Future. New York: Oxford University Press.

Buysse, Kristel, and Alain Verbeke. 2003. Proactive environmental strategies: A stakeholder management perspective. Strategic Management Journal 24: 453-70. [CrossRef]

Cabot, Jordi, Steve Easterbrook, Jennifer Horkoff, Lysanne Lessard, Sotirios Liaskos, and Jose-Norberto Mazón. 2009. Integrating Sustainability in Decision-Making Processes: A Modelling Strategy. Paper presented at International Conference on Software Engineering ICSE, Vancouver, BC, Canada, May 16-24; pp. 1-4.

Cefic. 2019. The European Chemical Industry Council. A Solution Provider for Sustainability. Available online: https://cefic.org/our-industry/a-solution-provider-for-sustainability/ (accessed on 13 November 2019).

Chernev, Alexander, and Sean Blair. 2015. Doing Well by Doing Good: The Benevolent Halo of Corporate Social Responsibility. Journal of Consumer Research 41: 1412-25. [CrossRef]

Collis, David. 1992. The Strategic Management of Uncertainty. European Management Journal 10: 125-35. [CrossRef]

Csutora, Mária. 2011. From eco-efficiency to eco-effectiveness? The policy-performance paradox. Society and Economy 33: 161-81. [CrossRef]

Darkow, Inga-Lena, and A. Heiko. 2013. Scenarios for the future of the European process industry-The case of the chemical industry. European Journal of Futures Research 1: 1-12. [CrossRef]

De Groot, Rudolf S., Rob Alkemade, Leon Braat, Lars Hein, and Louise Willemen. 2010. Challenges in integrating the concept of ecosystem services and values in landscape planning, management and decision making. Ecological Complexity 7: 260-72. [CrossRef]

Devinney, Timothy M. 2009. Is the Socially Responsible Corporation a Myth? The Good, the Bad, and the Ugly of Corporate Social Responsibility. Academy of Management Perspectives 23: 44-56. [CrossRef]

deVoil, P., Walter A. H. Rossing, and Graeme L. Hammer. 2006. Exploring profit-Sustainability trade-offs in cropping systems using evolutionary algorithms. Environmental Modelling \& Software 21: 1368-74.

Dyllick, Thomas, and Kai Hockerts. 2002. Beyond the business case for corporate sustainability. Business Strategy and the Environment 11: 130-41. [CrossRef]

Eidelman, Scott, and Christian S. Crandall. 2012. Bias in Favor of the Status Quo. Social and Personality Psychology Compass 6: 270-81. [CrossRef]

Elkington, John. 1997. Cannibals with Forks-The Triple Bottom Line of the 21st Century. Oxford: Capstone Publishing Limited.

Engert, Sabrina, Romana Rauter, and Rupert J. Baumgartner. 2016. Exploring the integration of corporate sustainability into strategic management: A literature review. Journal of Cleaner Production 112: 2833-50. [CrossRef]

Epstein, Marc J., and Marie-Josée Roy. 2001. Sustainability in Action: Identifiying and Measuring the Key Performance Drivers. Long Range Planning 34: 585-604. [CrossRef]

Epstein, Marc J., and Marie-Josée Roy. 2003. Making the Business Case for Sustainability: Linking Social and Environmental Actions to Financial Performance. Journal of Corporate Citizenship 9: 79-96. [CrossRef]

Epstein, Marc J., and Sally K. Widener. 2010. Identification and Use of Sustainability Performance Measures in Decision-Making. Journal of Corporate Citizenship 10: 42-73. [CrossRef]

Epstein, Marc J., and Priscilla S. Wisner. 2001. Using a Balanced Scorecard to Implement Sustainability. Environmental Quality Management 11: 1-10. [CrossRef]

Epstein, Marc J., Adriana Rejc Buhovac, and Kristi Yuthas. 2015. Managing Social, Environmental and Financial Performance Simultaneously. Long Range Planning 48: 35-45. [CrossRef]

Fifka, Matthias S. 2013. Corporate Responsibility Reporting and its Determinants in Comparative Perspective-A Review of the Empirical Literature and a Meta-analysis. Business Strategy and the Environment 22: 1-35. [CrossRef]

FTSE Russell. n.d. FTSE International Limited. FTSE4GOOD Europe Constituents. Available online: https: //www.ftserussell.com/products/indices/ftse4good (accessed on 27 November 2019).

Galpin, Timothy, J. Lee Whitttington, and Greg Bell. 2015. Is your sustainability strategy sustainable? Creating a culture of sustainability. Corporate Governance 15: 1-17. [CrossRef]

Garcés-Ayerbe, Concepción, Pilar Rivera-Torres, and Josefina L. Murillo-Luna. 2012. Stakeholder pressure and environmental proactivity. Management Decision 50: 189-206. [CrossRef] 
Gibson, Robert B. 2006. Beyond the Pillars: Sustainability Assessment as a Framework for effective Integration of Social, Economic and Ecological Considerations in Significant Decision-Making. Journal of Environmental Assessment Policy and Management 8: 259-80. [CrossRef]

Giunipero, Larry C., Robert E. Hooker, and Diane Denslow. 2012. Purchasing and supply management sustainability: Drivers and barriers. Journal of Purchasing and Supply Management 18: 258-69. [CrossRef]

Graham, John R., Campbell R. Harvey, and Shiva Rajgopal. 2005. The economic implications of corporate financial reporting. Journal of Accounting and Economics 40: 3-73. [CrossRef]

Haffar, Merriam, and Cory Searcy. 2017. Classification of Trade-offs Encountered in the Practice of Corporate Sustainability. Journal of Business Ethics 140: 495-522. [CrossRef]

Hahn, Tobias, Frank Figge, Jonatan Pinkse, and Lutz Preuss. 2010. Trade-offs in corporate sustainability: You can't have your cake and eat it. Business Strategy and the Environment 19: 217-29. [CrossRef]

Hahn, Tobias, Frank Figge, and Andrea Liesen. 2012. Assessing Trade-Offs in Investments for the Environment-The Case of a VOC-Reduction Investment at AUTO Group. Corporate Social Responsibility and Environmental Management 19: 114-28. [CrossRef]

Hart, Stuart L., and Glen Dowell. 2011. A Natural-Resource-Based View of the Firm. Journal of Management 37: 1464-79. [CrossRef]

Henry, Leona Aimée, Tine Buyl, and Rob J. Jansen. 2019. Leading corporate sustainability: The role of top management team composition for triple bottom line performance. Business Strategy and the Environment 28: 173-84. [CrossRef]

Hodgson, Damian E. 2004. Project Work: The Legacy of Bureaucratic Control in the Post-Bureaucratic Organization. Organization 11: 81-100. [CrossRef]

Hörisch, Jacob, R. Edward Freeman, and Stefan Schaltegger. 2014. Applying Stakeholder Theory in Sustainability Management. Organization \& Environment 27: 328-46.

IBM. 2008. The Enterprise of the Future: Global CEO Study. Available online: http:/globalforum.items-int.com/gf/ gf-content/uploads/2014/04/ceostudy2008_fullrep.pdf (accessed on 3 August 2019).

Kelemen, R. Daniel, and Tim Knievel. 2015. The United States, the European Union, and international environmental law: The domestic dimensions of green diplomacy. IJCLAW 13: 945-65. [CrossRef]

Kolstad, Ivar. 2007. Why Firms Should Not Always Maximize Profits. Journal Business Ethics 76: 137-45. [CrossRef]

Kuhlman, Tom, and John Farrington. 2010. What is Sustainability? Sustainability 2: 3436-48. [CrossRef]

Kuster, Jürg, Eugen Huber, Robert Lippmann, Alphons Schmid, Emil Schneider, Urs Witschi, and Roger Wüst. 2011. Handbuch Projektmanagement. 3 vols, Auflage. Berlin and Heidelberg: Springer.

Laverty, Kevin J. 1996. Economic "Short-Termism": The Debate, the Unresolved Issues, and the Implications for Management Practice and Research. Academy of Management Review 21: 825-60.

Liesen, Andrea, Frank Figge, and Tobias Hahn. 2013. Net Present Sustainable Value: A New Approach to Sustainable Investment Appraisal. Strategic Change 22: 175-89. [CrossRef]

Lipshitz, Raanan, and Orna Strauss. 1997. Coping with Uncertainty: A Naturalistic Decision-Making Analysis. Organizational Behavior and Human Decision Processes 69: 149-63. [CrossRef]

Lozano, Rodrigo. 2015. A Holistic Perspective on Corporate Sustainability Drivers. Corporate Social Responsibility and Environmental Management 22: 32-44. [CrossRef]

Margolis, Joshua D., Hillary Anger Elfenbein, and James P. Walsh. 2011. Does it Pay to Be Good ... And Does it Matter? A Meta-Analysis of the Relationship between Corporate Social and Financial Performance. Available online: https://ssrn.com/abstract=1866371 (accessed on 13 November 2019).

Meuser, Michael, and Ulrike Nagel. 2009. Das Experteninterview-konzeptionelle Grundlagen und methodische Anlage. In Methoden der Vergleichenden Politik- und Sozialwissenschaft: Neue Entwicklungen und Anwendungen. Edited by Susanne Pickel, Gert Pickel, Hans-Joachim Lauth and Detlef Jahn. Wiesbaden: VS Verlag für Sozialwissenschaften, pp. 465-79.

Matthew B. Miles, A. Michael Huberman, and Johnny Saldana. 2014. Qualitative Data Analysis. A Methods Sourcebook, 3rd ed. Thousand Oaks: SAGE Publications, Inc.

Miller, K. 2012. Organizational Communication. Approaches and Processes, 6th ed. Boston: Wadsworth Cengage Learning.

Morris, Michael W., and Steven K. Su. 1999. Social Psychological Obstacles in Environmental Conflict Resolution. American Behavioral Scientist 42: 1322-49. [CrossRef] 
Nidumolu, Ram, C.K. Prahalad, and M.R. Rangaswami. 2009. Why Sustainability Is Now the Key Driver of Innovation. Available online: https://hbr.org/2009/09/why-sustainability-is-now-the-key-driver-ofinnovation (accessed on 13 November 2019).

Oertwig, Nicole, Mila Galeitzke, Hans-Georg Schmieg, Holger Kohl, Roland Jochem, Ronald Orth, and Thomas Knothe. 2017. Integration of Sustainability into the Corporate Strategy. In Sustainable Manufacturing: Challenges, Solutions and Implementation Perspectives. Edited by Rainer Stark, Günther Seliger and Jérémy Bonvoisin. Berlin and Heidelberg: Springer, pp. 175-200.

Olsson, Rolf. 2008. Risk management in a multi-project environment. International Journal of Quality E Reliability Management 25: 60-71.

Pagell, Mark, and Zhaohui Wu. 2009. Building a More Complete Theory of Sustainable Supply Chain Management Using Case Studies of Ten Exemplars. Journal of Supply Chain Management 45: 37-56. [CrossRef]

Pedersen, Esben Rahbek Gjerdrum. 2011. All animals are equal, but ... : Management perceptions of stakeholder relationships and societal responsibilities in multinational corporations. Business Ethics: A European Review 20: 177-91. [CrossRef]

Perminova, Olga, Magnus Gustafsson, and Kim Wikström. 2008. Defining uncertainty in projects-A new perspective. International Journal of Project Management 26: 73-79. [CrossRef]

Placier, Klara. 2011. The Impact of Recession on the Implementation of Corporate Social Responsibility in Companies. Journal of Competitiveness 3: 83-96.

Porter, Michael E., and Mark R. Kramer. 2011. Creating Shared Value: How to reinvent capitalism-And unleash a wave of innovation and growth. Harvard Business Review 89: 62-77.

Retief, Francois, Angus Morrison-Saunders, Davide Geneletti, and Jenny Pope. 2013. Exploring the psychology of trade-off decision-making in environmental impact assessment. Impact Assessment and Project Appraisal 31: 13-23. [CrossRef]

Revell, Andrea, David Stokes, and Hsin Chen. 2010. Small businesses and the environment: Turning over a new leaf? Business Strategy and the Environment 19: 273-88.

Reynolds, Scott J., Frank C. Schultz, and David R. Hekman. 2006. Stakeholder Theory and Managerial Decision-Making: Constraints and Implications of Balancing Stakeholder Interests. Journal of Business Ethics 64: 285-301. [CrossRef]

Robbins, Stephen P., and Mary A. Coulter. 2016. Management, 13th ed. Boston: Pearson.

Walker, Helen, Stefan Seuring, Joseph Sarkis, Robert Klassen, Jens K. Roehrich, Johanne Grosvold, and Stefan U. Hoejmose. 2014. Reputational risks and sustainable supply chain management. International Journal of Operations \& Production Management 34: 695-719.

Salzmann, Oliver, Aileen Ionescu-Somers, and Ulrich Steger. 2005. The Business Case for Corporate Sustainability. European Management Journal 23: 27-36. [CrossRef]

Samuelson, William, and Richard Zeckhauser. 1974. Status Quo Bias in Decision Making. Journal of Risk and Uncertainty 1: 7-59. [CrossRef]

Schaltegger, Stefan, Florian Lüdeke-Freund, and Erik G. Hansen. 2012. Business cases for sustainability: The role of business model innovation for corporate sustainability. IJISD 6: 95-119. [CrossRef]

Schmidt, Günter, and Wilbert E. Wilhelm. 2000. Strategic, tactical and operational decisions in multi-national logistics networks: A review and discussion of modelling issues. International Journal of Production Research 38: 1501-23. [CrossRef]

Sharma, Sanjay, and Irene Henriques. 2005. Stakeholder influences on sustainability practices in the Canadian forest products industry. Strategic Management Journal 26: 159-80. [CrossRef]

Simon, Herbert A. 2000. Bounded rationality in social science: Today and tomorrow. Mind E Society 1: 25-39.

Slevin, Dennis P., and Jeffrey K. Pinto. 1987. Balancing strategy and tactics in project implementation. Sloan Management Review 29: 33-41.

Sukitsch, Martina, Sabrina Engert, and Rupert J. Baumgartner. 2015. The Implementation of Corporate Sustainability in the European Automotive Industry: An Analysis of Sustainability Reports. Sustainability 7: 11504-31. [CrossRef]

Tang, Mingfeng, Grace Walsh, Daniel Lerner, Markus A. Fitza, and Qiaohua Li. 2018. Green Innovation, Managerial Concern and Firm Performance: An Empirical Study. Business Strategy and the Environment 27: 39-51. [CrossRef] 
Teng, Mei-Jane, Shih-Ying Wu, and Stephen Jui-Hsien Chou. 2014. Environmental Commitment and Economic Performance-Short-Term Pain for Long-Term Gain. Environmental Policy Governance 24: 16-27. [CrossRef]

Tînjală, Diana-Maria, Lavinia Mirela Pantea, and Alexandru Buglea. 2015. 2010-2014: A Comparative Evolution of Sustainability Reporting and Its Assurance in Europe and the U.S.A. Timisoara Journal of Economics and Business 8: 48-69. [CrossRef]

Certo, S. Trevis, Brian L. Connelly, and Laszlo Tihanyi. 2008. Managers and their not-so rational decisions. Business Horizons 51: 113-19. [CrossRef]

Tversky, Amos, and Daniel Kahneman. 1974. Judgement under Uncertainty: Heuristics and Biases. Sciences 185: 1124-31. [CrossRef] [PubMed]

Ullmann, Arieh A. 1985. Data in Search of a Theory: A Critical Examination of the Relationships among Social Performance, Social Disclosure, and Economic Performance of U.S. Firms. AMR 10: 540-57.

Varenova, Daria, Martin Samy, and Alan Combs. 2013. Corporate social responsibility and profitability: Trade-off or synergy. Sustainability 4: 190-215. [CrossRef]

VCI. n.d. Verband der Chemischen Industrie e. V. Sustainability in VCI. Available online: https://www.vci.de/dervci/nachhaltigkeit-im-vci/uebersicht.jsp (accessed on 13 November 2019).

Verband der Automobilindustrie. 2018. Jahresbericht 2018. Available online: https:/www.vda.de/de/services/ Publikationen/jahresbericht-2018.html (accessed on 24 August 2020).

Vogel, David, Michael Toffel, Diahanna Post, and Nazli Uludere Aragon. 2010. Environmental Federalism in the European Union and the United States. SSRN Journal, 1-41. [CrossRef]

von Wehrden, Henrik, Lydia Kater-Wettstädt, and Uwe Schneidewind. 2019. Fridays for Future aus nachhaltigkeitswissenschaftlicher Perspektive. GAIA Ecological Perspectives for Science and Society 28: 307-9. [CrossRef]

Walker, Kent, Na Ni, and Bruno Dyck. 2015. Recipes for Successful Sustainability: Empirical Organizational Configurations for Strong Corporate Environmental Performance. Business Strategy and the Environment 24: 40-57. [CrossRef]

Whelan, Tensie, Bruno Zappa, Rodrigo Zeidan, and Greg Fishbein. 2017. How to Quantify Sustainability's Impact on Your Bottom Line. Available online: https:/hbr.org/2017/09/how-to-quantify-sustainabilitys-impact-onyour-bottom-line (accessed on 13 November 2019).

Winn, Monika, Jonatan Pinkse, and Lydia Illge. 2012. Case Studies on Trade-Offs in Corporate Sustainability. Corporate Social Responsibility and Environmental Management 19: 63-68. [CrossRef]

Witzel, Andreas. 2000. Das problemzentrierte Interview. Forum Qualitative Sozialforschung/Forum: Qualitative Social Research 1: 1-13.

Wu, Zhaohui, and Mark Pagell. 2011. Balancing priorities: Decision-making in sustainable supply chain management. Journal of Operations Management 29: 577-90. [CrossRef]

Wu, Tungju, Yenchun Jim Wu, Hsientang Tsai, and Yibin Li. 2017. Top Management Teams' Characteristics and Strategic Decision-Making: A Mediation of Risk Perceptions and Mental Models. Sustainability 9: 2265. [CrossRef]

(C) 2020 by the author. Licensee MDPI, Basel, Switzerland. This article is an open access article distributed under the terms and conditions of the Creative Commons Attribution (CC BY) license (http://creativecommons.org/licenses/by/4.0/). 